مؤشرات تخطيطية لتفعيل تطبيق الثفافية الإدارية بمنظمات الخدمات الاجتماعية

\author{
اعداد \\ محمد عبد العال عبد العزيز \\ مدرس بكلية الخدمة الاجتماعية جامعة الفيوم
}


مجلة كلية الخدمة الاجتماعية للار اسات و البحوث الاجتماعية - جامعة الفيوم 


\section{ملخص البصث}

أن نجاح الإدارة في أداء وظائفها ،أمور لا يمكن تحقيقها إلا مع وجود مبدأ عام

للشفافية والمشاركة في مختلف العمليات الإدارية،وفي مختلف المؤسسات عامة كانت أم خاصة،مع الأخذ بعين الاعتبار أن الأزمات الحديثة تشهد تطورات في حقل الاتصالات والثورة التكنولوجية,وان التتظيمات المنفتحة تقبل التغير النابع من ثقافة المجتمعروهو الأمر الذي يحتم البحث عن المضمون الصحيح للشفافية والمسائلة والانفتاح التي تعتبر من

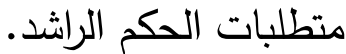

وتعتبر الثفافية الإدارية من المفاهيم الإدارية الحديثة والمتطورة التي يتوجب على

الإدارات الواعية ضرورة الأخذ بها،لما لها من أهمية في إحداث التتمية الإدارية الناجحة،إضافة إلى مساهماتها في تنمية التظظيمات الإدارية والوصول إلى بناء تتظيمي سليم قادر على مواجهة التحديات الجديدة والتغيرات المحيطة،حيث دعا الكثير من رواد الفكر الإداري إلى ضرورة بذل الجهود لمعالجة المشاكل الإدارية والتعرف على المعوقات التي تواجه التتمية الإدارية,والغموض في أساليب العمل وإجراءاته،من هنا جاءت الدراسة الراهنة بعنوان: مؤشرات تخطيطية لتفعيل تطبيق الثفافية الإدارية فى منظمات الخدمات الاجتماعية.

وقد تم استخدام منهج المسح الإجتماعى بطريقة الحصر الشامل للعاملين بمديرية التضامن الاجتماعى بمحافظة الفيوم,حيث بلغ عدد المبحوثين(278)عامل فى كافة الإدارات والأقسام التابعة للمنظمة.وإستهفت الدراسة تحديد واقع تطبيق الثفافية الإدارية بمنظمات الخدمات الاجتماعية من خلال أبعادها الأساسية المتمثلة فى نظم المعلومات إجراءات المسائلة والمحاسبية,نظام الاتصال القائم,اللوائح والإجراءات وآليات العمل بالمنظمة,مشاركة العاملين فى اتخاذ القرارات الإدارية,كما هدفت الدراسة تحديد المعوقات التى تحد من تطبيق الثفافية الإدارية بمنظمات الخدمات الاجتماعية وتوصلت الدراسة فى نتائجها أن واقع تطبيق الثفافية الإدارية بمنظمات الخدمات الاجتماعية متوسط كما توصلت الدراسة إلى مجموعة من المؤشرات التخطيطية لتفعيل تطبيق الشفافية الإدارية بأبعادها المختلفة بهذه المنظمات. الكلمات المفتاحية: المؤشرات , الشفافية الإدارية , المنظمات, الخدمات الاجتماعية 


\section{Search Summary}

The success of the department in the performance of its functions can only be achieved with the existence of a general principle of transparency and participation in various administrative processes, and in various institutions, public or private, bearing in mind that recent crises are witnessing developments in the field of communications and the technological revolution, and that open organizations accept the change emanating from the culture of society, which necessitates the search for the correct content of transparency, accountability and openness that is considered a requirement of adult governance.Administrative transparency is one of the modern and evolving management concepts that conscious departments must adopt, because of their importance in achieving successful administrative development, in addition to their contributions to the development of administrative organizations and access to sound organizational building capable of meeting new challenges and changes surrounding, Where many pioneers of administrative thought called for the need to make efforts to address administrative problems and identify the obstacles facing administrative development, and ambiguity in working methods and procedures, hence the current study entitled: Planning Indicators to activate the application of administrative transparency in social services organizations.

The social survey method was used in a comprehensive inventory of employees in the Directorate of Social Solidarity in Fayoum governorate, where the number of researchers reached 278 workers in all departments and departments of the organization. The study also aimed to identify the obstacles that limit the application of administrative 
transparency in social services organizations and the study concluded in its results that the reality of applying administrative transparency in social services organizations is average as the study reached a set of planning indicators to activate the application of administrative transparency in its various dimensions in these organizations.

Keywords Indicators: Administrative Transparency, Organizations, Social Services 


\section{أولا:مدخل الاراسة والاراسات السابقة :}

شهدت السنوات الأخيرة تطورات ملحوظة في أنماط المنظمات والتنظيمات الإجتماعية والثقافية والسياسية ، كما تتوعت أهداف هذه المنظمات حسب إحتياجات ومتطلبات الإنسان في المجتمعات الحديثة ، التي تزداد بصورة مطردة في الوقت الحالي وبعد أن فتح المجال أمام العديد من أنماط المنظمات الإجتماعية لتمارس نشاطها وخدماتها بعيداً عن هيمنة السلطة السياسية،أو الحكومية،خاصة بعد تقلص دور الدولة في العديد من المجالات الإجتماعية والثقافية والإعلامية وإعطاء الفرصة لإسهامات القطاع الأهلي لممارسة دوره في تحقيق مستويات أفضل من الرعاية والخدمات الإجتماعية.( هلالي ,محمود محمد,2013,ص22) كما ازداد الحديث أيضاً عن الدور الذى يمكن أن تقوم به هذه المنظمات لسد الفجوة بين القطاع الخاص والحكومة لمقابلة متطلبات التتمية،لذلك فقد بدأت تتغير نظرة العالم لتلك المؤسسات واعتبارها مصدر فعال يُعتمد عليها فى تطبيق مختلف السياسات ومواجهة الكثير من المشكلات المجتمعية،حيث أن هذه المؤسسات تعد أكثر ديناميكية ومرونة من الجهات الحكومية فى الوصول لكثير من الفئات الفقيرة التى لا تستطيع أن تصل لها الحكومة. لسمك

$$
\text { نجوى ,صدقى,السيد, 2002,ص5) }
$$

بيد أن نجاح الإدارة في أداء وظائفها،أمور لا يمكن تحقيقها إلا مع وجود مبدأ عام للشفافية والمشاركة في إدارة كافة الثؤون العامة في الدولة وفي مختلف مؤسساتها عامة كانت أم خاصة،مع الأخذ بعين الاعتبار أن الأزمات الحديثة تشهد تطورات في حقل الاتصالات والثورة التكنولوجية,وأن التظيمات المنفتحة تقبل التغيير النابع من ثقافة المجتمع,وعلى الإدارة أن تأخذ بجهود الإصلاح والإدارة بالثفافية,وهو الأمر الذي يحتم البحث عن المضمون الصحيح للشفافية والمسائلة التي تعتبر من متطلبات الحكم الراشد. وتعد الثفافية الإدارية من المفاهيم الإدارية الحديثة والمتطورة التى يستوجب على الإدارات الواعية ضرورة الأخذ بها لما لها من أهمية فى إحداث التتمية الإدارية الفاعلة,بالإضافة إلى مساهمتها فى تتمية التظيمات الإدارية والوصول من خلالها إلى يناء تتظيمى سليم قادر على مواجهة التحديات الجديدة والتغيرات المحيطة.(حامد,حسين إبراهيم, 2009,ص25) ولقد ظهر مفهوم الشفافية الإدارية مع الاتجاه نحو الأخذ بالحوكمة فى إدارة شئون الدولة بإعتبارها مدخلا لإصلاح المنظمات الحكومية,حيث ترتكز على التزام الإدارة بإشراك المواطنين فى إدارة الثئون العامة التى تمارسها الإدارة لصالح المواطنين مع الالتزام باتخاذ كافة التدابير 
التى تتضمن تزويد المواطنين بالبيانات والمعومات الصادقة عن كافة أنثطتها وموازنتها

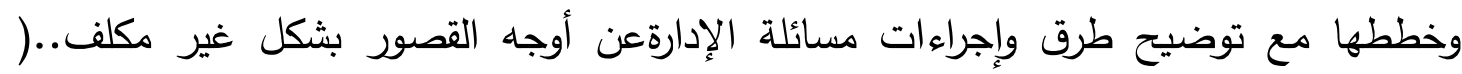

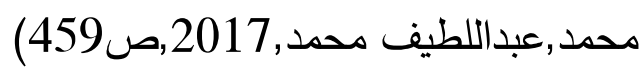

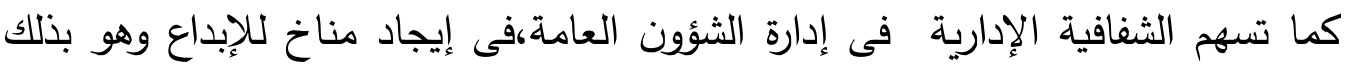

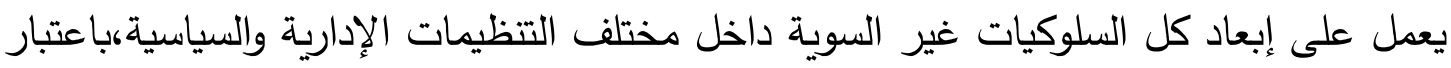

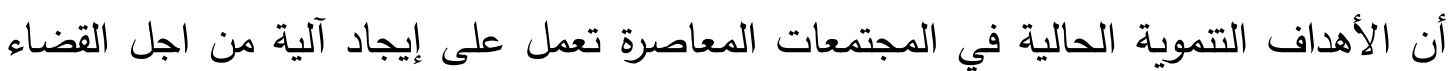

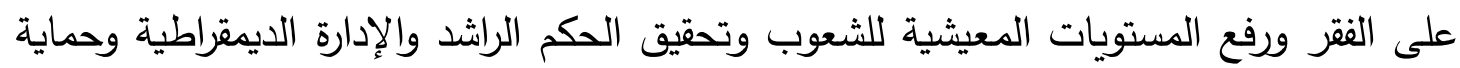
حقوق الإنسان والإصلاح الإداري،والسياسي والاقتصادي والاجتماعي والتعليمي والابتكار التطويري والوقاية من الفساد.

بالإضافة إلى ذلك تعد الثفافية الإدارية من المفاهيم الإدارية الحديثة التي تتتاول في

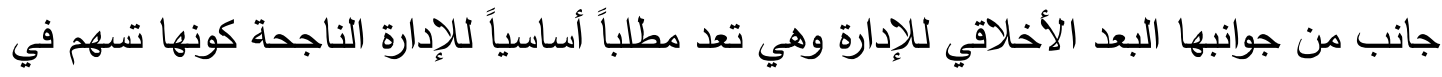
تتمية التظيمات الإدارية,وتقودها إلى مواجهة التغيرات العالمية المتسارعة(حوامدة،وجرادات، لإنداته

حيث دعى الكثير من رواد الفكر الإداري إلى ضرورة بذل الجهود لـعالجة المشاكل

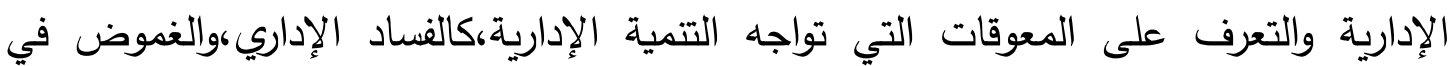
أساليب العمل وإجراءاته،فكانت محاولات تطبيق الثفافية في العمليات الإدارية،من الأمور الهامة الإدادية الواجب مراعاتها في الممارسات الإدارية.

ويوكد ذلك ما استهدفته دراسة(مشرف العمرى,2013),التعرف على درجة ممارسة الثفافية الإدارية فى الجامعات السعودية ومعوقاتها وطرق تحسينها من وجهة نظر أعضاء هيئة

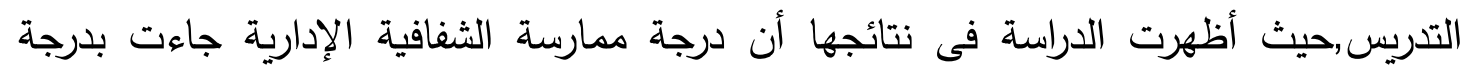

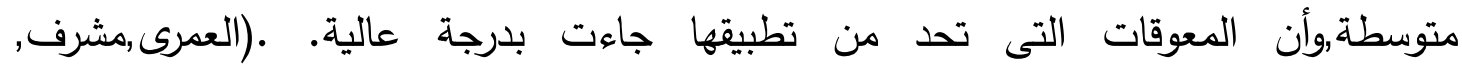
(243),2013

كما استهدفت دراسة (إبراهيم مدكور ,2013),تحديد معوقات ممارسة الثفافية الإدارية فى

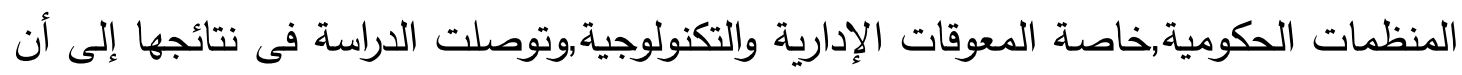

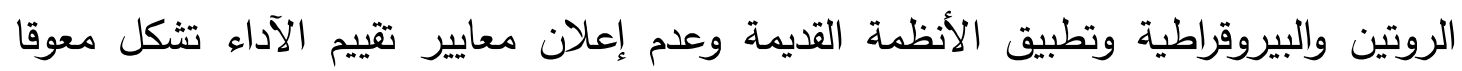

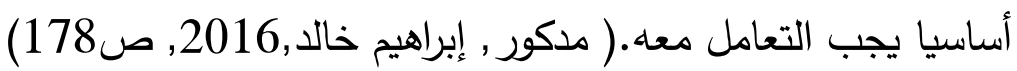


إن ممارسة الثفافية فى أى مجتمع من شأنها أن تؤدى إلى تحقيق العديد من المزايا

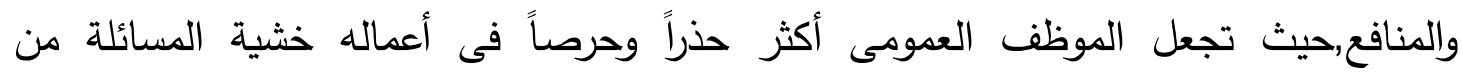
المواطنين فضلاًعن أنها تسهم فى توسيع فرص المشاركة لجميع الأطراف ذات الصلة,بجانب

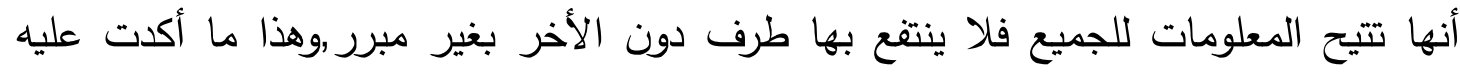
دراسة (حنان الأحمدى,2017),والتى إستهدفت التعرف على درجة ممارسة قائدى الهيئات التعليمية للثفافية الإدارية,حيث كثثت الدراسة أن إتباع الإدارة للثفافية من شأنه أن يحقق آدهاً

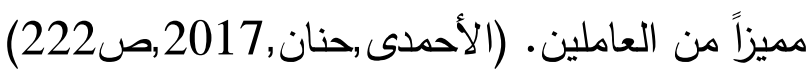

كما استهدفت دراسة (Liepertp,Gary,2005),تحديد مميزات تطبيق الثفافية الإدارية فى المؤسسات المحلية,حيث توصلت فى نتائجها أن تطبيق الثفافية الإدارية من شأنه أن يحقق الإدانه

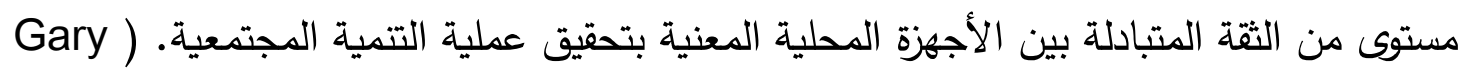
(,Liepertp 2005

وأثارت دراسة (Hall Kier Bente,2007) إلى تحديد علاقة الثفافية الإدارية وعملية صنع القرارات فى المنظمات الحكومية,حيث أظهرت نتائج الدراسة أهمية شفافية ومصداقية المعلومات

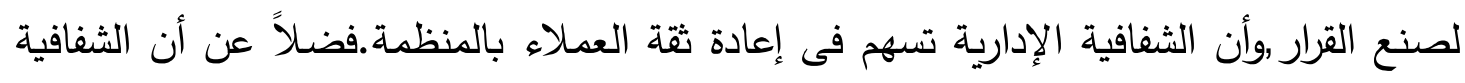
تتيح المعلومات اللازمة لوضع أسس إستراتيجية لمواجهة التحديات المختلفة. ( Bente ,Hall)

Kier,2007

كما تثكل الثفافية الإدارية إحدى أهم الأدوات التى تساعد فى تعزيز مسيرة التتمية فى

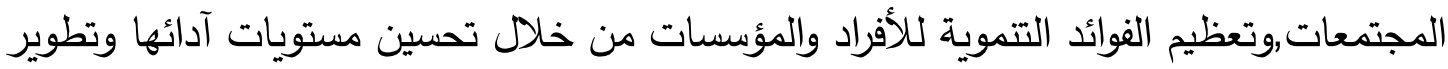
قدرتها لهذه المواجهة من خلال عملية تحسين الآداء المؤسىى لإعتبارها عملية متكاملة تنطوى على أنثطة مخططة وشاملة بالمؤسسة,حيث تتم وفق إستراتيجيات وخطط وبرامج واضحة ومحددة,وهذا ما أكدت عليه دراسة(Shane,Kite,2003),أن توافر الثفافية يزيد بشكل إيجابى ولئي من فرص التطوير والتدعيم,وكفاءة العمل وسرعة الإنجاز وكذا الرضا الوظيفى للعاملين بالمنظمات. (Kite ,Shane ,2003.p53 ) مصن كما أشارت دراسة(Klein,J,2012),إلى الكشف عن مساهمة الثفافية التظظيمية فى الحد من الصراع بين مديرى المؤسسات التعليمية والعملية,حيث أظهرت الدراسة فى نتائجها وجود علاقة 
ذات دلالة إحصائية بين تحقيق الثفافية الإدارية وإنجاز مهام العمل المكلفين بها. (Klein,J,2012,p550)

كما استهدفت دراسة(محمد علام,2014),التعرف على ممارسة الثفافية الإدارية ودعم عملية صنع القرار بالمنظمات الحكومية وتوصلت إلى ضرورة تحرى المصداقية والثفافية فى مناقشة الآراء المطروحة مع الإعلان عن القرارات المتخذة بنوع من الوضوح لجميع العاملين. (علام (2014, (2014)

بينما إستهدفت دراسة(Hazel Korn,2012),التعرف على الأدوات المناسبة التى يمكن أن توفر قدراً من الثفافية المطلوبة للمستقيدين من الخدمات التى تقدمها المؤسسات الخدمية فى إيرلندا,حيث كشفت الدراسة فى نتائجها وجود تأثير بدرجة كبيرة فى استخدام قيادات المؤسسات الخدمية لعدد من الأدوات الرئيسية لدعم الثفافية,ومتطلبات تطبيقها,لتحقيق النزاهة والمحاسبية وفق مبدأ الثواب والعقاب وتطوير اللوائح والقوانين وتحديثها بإستمرار بما يحقق تدفق المعلومات ووصولها بسهولة ويسر للمستفيدين. (Korn,Hazel,2012, p81) وبناء على ما تم عرضه من بحوث ودراسات وحقائق مستنتجة يتضح ارتباطها بالثفافية الإدارية والتى أضحت أحد الموضوعات المهمة للمهتمين بالعملية التتموية بمنظمات الخدمات الاجتماعية وأهم المداخل التي تستهدف تحقيق أهداف هذه المنظمات وضمان بقائها وإستمرارها فى ظل ما تشهده من تحديات,من هنا تتمثل القضية المحورية للدراسة الراهنة في تفعيل تطبيق الثفافية الإدارية بمنظمات الخدمات الاجتماعية من خلال مجموعة من المؤشرات التخطيطية لتحقيق ذلك ثانتًا : أهمية الاراسية: تنطلق أهمية الدراسة الحالية من الإعتبارات التالية :1. الإهتمام القومي والعالمي بمنظمات الخدمات الاجتماعية وماتقدمه من أدوار فى ظل المتغيرات الراهنة التي يمر بها المجتمع.

2. تعاظم الدور الذى يمكن أن تحققه الثفافية الإدارية في النهوض بدور المنظمات الاجتماعية خاصة في ظل عجز الدولة عن تلبية وإشباع العديد من الإحتياجات المجتمعية. 
3. أهمية موضوع الثفافية الإدارية كأحد وأهم الموضوعات الأساسية التي تؤثر على كفاءة

وفعالية منظمات الخدمات الاجتماعية وطبيعة ونوعية الخدمات التي تقدمها. 4. تعد الثفافية الإدارية المؤشر الذي يقيس نجاح المنظمة في تحقيق أهدافها وقرتها على البقاء والنمو.ويحقق نوع من الإنتمرارية للمنظمة. 5. تمثل هذه الدراسة محاولة لمواصلة السعى الحثيث لزيادة قدرة المنظمات الأهلية التى تتعامل مع الخدمات الاجتماعيةعلى تحسين مستوى خدماتها وإرضاء جمهور المتعاملين معها. 6. توجه هذه الدراسة نظر إدارة منظمات الخدمات الاجتماعية الأهلية إلى أهمية تطبيق الثفافيةا الإدارية كأداة فاعلة لتحقيق معدلات مرتفعة من الانجاز بالمنظمة. 7. قد تسهم هذه الدراسة في إدداد مدراء منظمات الخدمات الاجتماعية بطبيعة وسبل تفعيل الثفافية الإدارية بهذه النوعية من المنظمات.

ثالثا: أهداف الدراسية:.

\section{تسعى هذه الاراسة إلى تحقيق هدف رئيسي مؤداه :-}

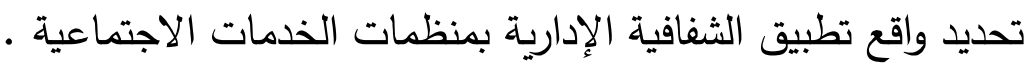

\section{وينبثق من هذا الههف الرئيسي مجموعة من الأهداف الفرعية هي : -}

أ-تحديد واقع تطبيق الثفافية الإدارية فى ضوء نظم المعلومات بمنظمات الخدمات الاجتماعية ب- تحديد واقع تطبيق الثفافية الإدارية فى ضوء نمط الاتصال القائم بمنظمات الخدمات الاجتماعية

ج- تحديد واقع تطبيق الثفافية الإدارية فى ضوء المسائلة والمحاسبية بمنظمات الخدمات

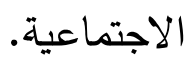
د- تحديد واقع تطبيق الثفافية الإدارية فى ضوء مشاركة العاملين فى إتخاذ القرارات بمنظمات

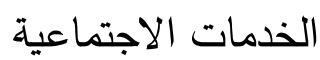
هـ تحديد واقع تطبيق الثفافية الإدارية فى ضوء اللوائح والإجراءات والقوانين بمنظمات الخدمات

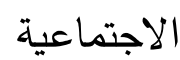
2- تحديد أهم المعوقات التي تحد من تطبيق الثفافية الإدارية بمنظمات الخدمات الاجتماعية. 3- التوصل إلى مؤشرات تخطيطية لتفعيل تطبيق الثفافية الإدارية بمنظمات الخدمات الاجتماعية 
رابعا:تساؤلات الاراسة:

تسعى هذه الدراسة إلى طرح مجموعة من التساؤلات الرئيسة مؤداه : -

" ما واقع واقع تطبيق الثفافية الإدارية بمنظمات الخدمات الاجتماعية ؟

وينبثق من هذا التساؤل الرئيسي عدة تساؤلات فرعية هي :-

أ- ما واقع تطبيق الشفافية الإدارية فى ضوء نظم المعلومات بمنظمات الخدمات الاجتماعية؟ ب - ما واقع تطبيق الثفافية الإدارية فى ضوء نمط الاتصال القائم بمنظمات الخدمات الاجتماعية؟

ج- ما واقع تطبيق الثفافية الإدارية فى ضوء المسائلة والمحاسبية بمنظمات الخدمات الاجتماعية؟ د- ما واقع تطبيق الثفافية الإدارية فى ضوء مشاركة العاملين فى اتخاذ القرارات بمنظمات الخدمات الاجتماعية ؟ هـ ما واقع تطبيق الثفافية الإدارية فى ضوء اللوائح والإجراءات والقوانين بمنظمات الخدمات الاجتماعية ؟

2- ما المعوقات التي تحد من تطبيق الثفافية الإدارية بمنظمات الخدمات الاجتماعية ؟ 3- ما المؤشرات التخطيطية لتفعيل تطبيق الثفافية الإدارية بمنظمات الخدمات الاجتماعية ؟ خامسا: المفاهيم الرئيسة للدراسة : تعتمد الدراسة الحالية على المفاهيم التالية:1- المؤشرات التخطيطية

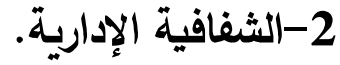
3-الخدمات الاجتماعية وفيما يلي عرض توضيحي لكل مفهوم من هذه المفاهيم كما يليـيـ Planning Indicators - المؤشرات التخطيطية

يأخذ مفهوم المؤشرات مسميات مثل الاتجاهات(أي مؤشر الحركة أو مؤشر التغير)،وإن كان يتعين ذكره أن مصطلح المؤشرات التخطيطية يتضمن نوعية من المؤشرات الفرعية،وهي المؤشرات الاجتماعية والاقتصادية،غير أن مصطلح المؤشرات الاقتصادية كان لله السبق في الظهور من مصطلح المؤشرات الاجتماعية،حيث أرجع النجاح النسبي الذي حققته المؤشرات 
الاقتصادية في توجيه السياسة الاقتصادية إلى بعض العلماء الاجتماعيي.

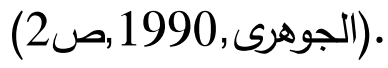

وترجع أهمية دراسة المؤشرات التخطيطية فى التعرف على تتابع الاتجاهات أو التطورات

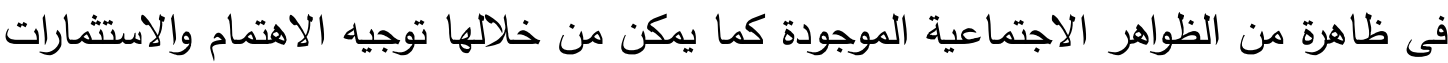

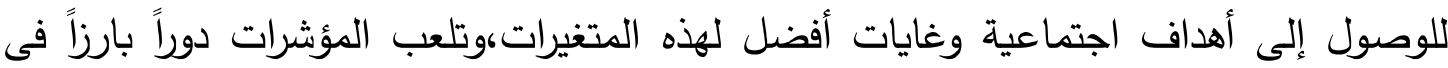

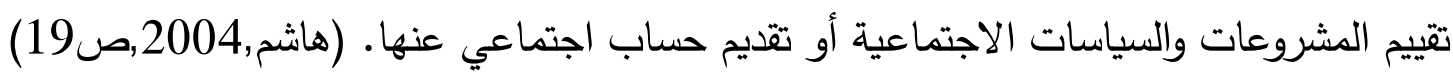
وفي ضوء ذلك يعرف المؤشر التخطيطي بأنه مقياس كمي للأوضاع الاجتماعية التى فئ

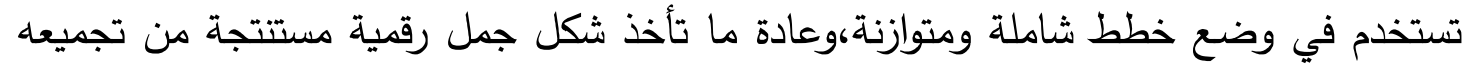

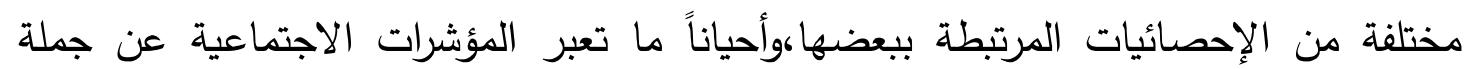
بسيطة لوضع أو عرض معين مرتبط بمشكلة اجتماعية معينة،وتعتبر المؤشرات التخطيطية

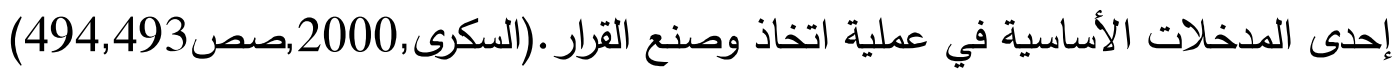
وتعرف المؤشرات التخطيطية بأنها بيانات كمية أو كيفية ترصد الواقع الفعلي لنوعية حياة

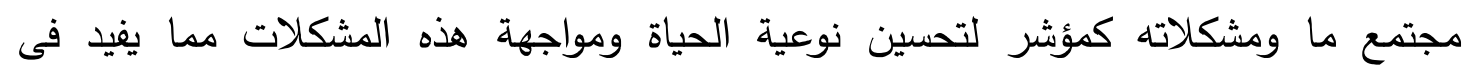

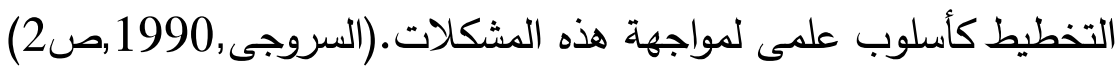

ويرى البعض أن المؤشرات التخطيطية تمثل مقياس كمى للأوضاع الاجتماعية الهامة

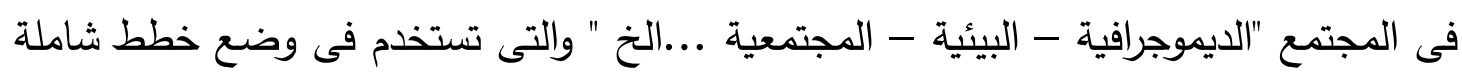

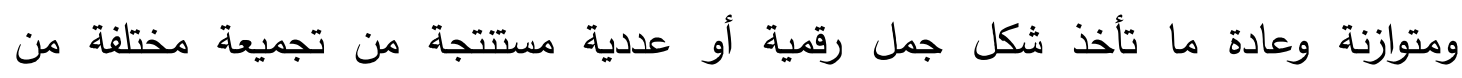

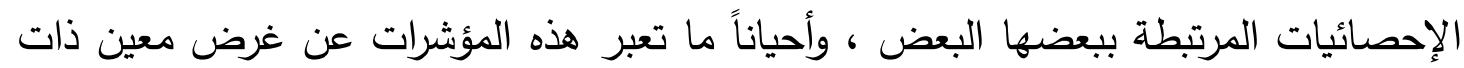
الصلة بمشكلة اجتماعية معينة. (Barnes, Barry1995,p15)

وهناك من عرف المؤشرات التخطيطية بأنها : بيانات كمية أو كيفية ترصد الواقع لحياة

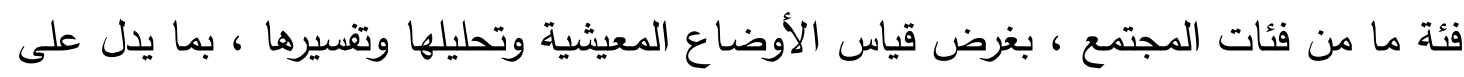
واقع هذه الفئة مما يساعد فى وضع خطط تسهم فى تحسين وتطوير نوعية الحياة لتلك الفئة (ناجى, 2002, (28). 
وفى ضوء ما تم عرضه من تعريفات تناولت مفهوم المؤشرات التخطيطية أوضحت

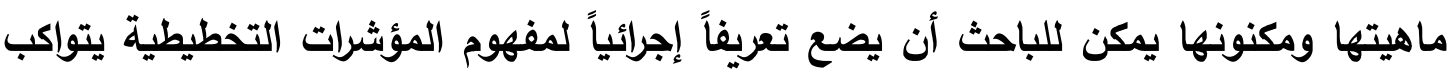

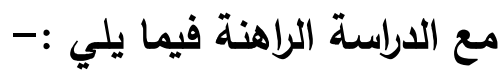

تلك البيانات الكمية والنوعية التى ترصد الواقع الفعلي لتطبيق الثفافية الإدارية بمنظمات

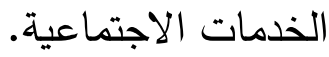

يمكن من خلالها تحديد جوانب القصور والقوة فى تطبيق الثفافية الإدارية بمنظمات

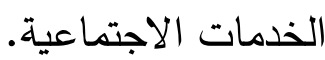

ت تقيد فى التوصل لمجموعة من القزارت التى تخلم تطيق الثفافية الإدارية بمنظمات الخدمات الاجتماعية. يتم الاستفادة من هذه المؤشرات فى التعامل بنوع من الفعالية مع المشكلات التى تعوق تطبيق الثفافية الإدارية بمنظمات الخدمات الاجتماعية.

\section{2- مفهوم الثفافية الإدارية}

تعد الثفافيةالإدارية من المفاهيم الحديثة والمعاصرة التي كانت محط اهتمام الكثير من المفكرين وهذا بسبب تطور وسائل الإعلام والاتصال التي ساهمت بثكل كبير في ظهور واتساع

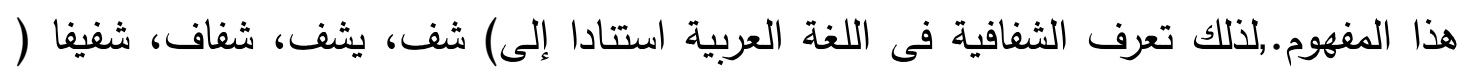
بفتح أو كسر الثين والتي تعني الرقة وخفة الحال،أو قابلية الثيء لإظهار ما وراءه وبالتالي

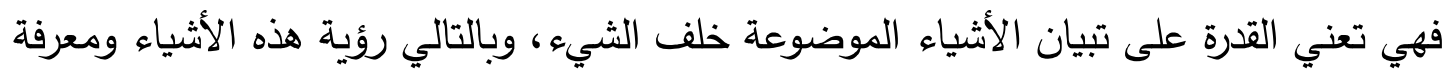

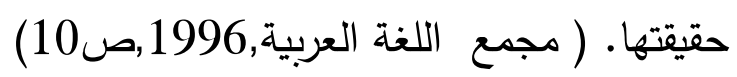

كما تعرف الثفافية بأنها" ضرورة وضوح العلاقة مع الجمهور ، فيما يخص إجراءات تقديم

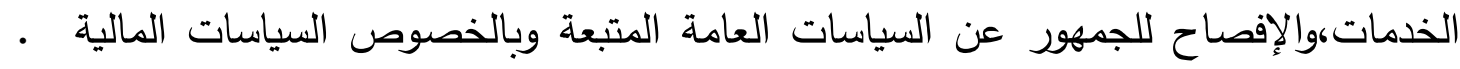
العامة،وحسابات القطاع العام، وكيفية إدارة الدولة من قبل القائمين عليها بمختلف مستوياتهر .

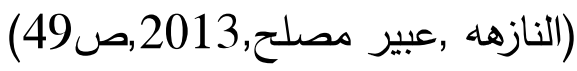

كما تعنى الثفافية تقاسم المعلومات والمكاشفة فهي تضمن التدفق الحر والثامل والوصول للمعلومات بحيث تصبح متاحة للجميع، وتوفر إجراءات واضحة فيما بين أصحاب المصلحة

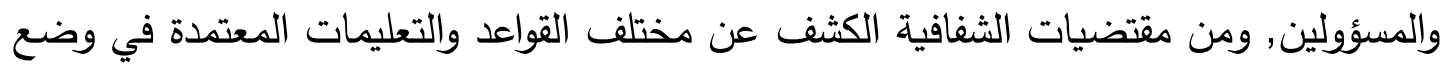


وتتفيذ السساسات واتخاذ القرارات بحيث تسح فيما بعد بالمحاسبة والمساءلة.(مسفر ,فهد بن عبد

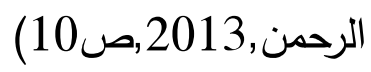

بينما يشير مفهوم الثفافية إلى الوضوح والتبيان في كل مجالات العمل التي تتم بين الإدارة العليا والمستويات الإدارية الأخرى، بحيث تكون المعلومة متاحة للجميع كل حسب اختصاصه، وذلك للإفادة منها في أداء المهام المنوطة لعاملين(عبد الحليم وعبابنة، $(58 ص, 2006$,

و تعني الثفافية أن المعلومات المتعلقة بالسياسة العامة للدولة تكون معلومة واضحة ومنظورة ومفهومة من قبل الشعب، وعلى الحكومة أن تتبني سياسة الابتعاد عن الحكم الثمولي وتوسيع (i)" الديمقراطية

كما يقصد بالثفافية "حق كل مواطن في الوصول الى المعلومات، ومعر فة آليات اتخاذ القرار المؤسسي، وحق الثفافية متطلب ضروري لوضع معايير أخلاقية وميثاق عمل مؤسسي، لما تؤدي إليه من الثقة وكذلك المساعدة على اكتشاف الفساد.( (مخيمر وآخرون, 2000, ص105)

وهنالك من يرى أن) : الثفافية في الإدارة الحكومية تعني "أن تكون الحكومة والأجهزة الإدارية العامة في صندوق من زجاج، بحيث يرى الجميع بوضوح ما تقوم به من أعمال، وما

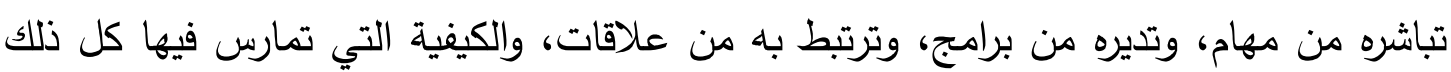
(أفندي، 2002, ص 261).

كما أن الثفافية الإدارية تعنى: الوضوح التام فى رسم الخطط والسياسات واتخاذ القرارات,وخضوع الممارسات الإدارية للمراقبة المستمرة,وسهولة الوصول للمعلومات,كما أن ذلك من شأنه أن يعزز مفاهيم التتمية العادلة,ومكافحة الفساد الإدارى من خلال تعزيز الثقة بين المنظمة والعاملين والعملاء .(الغالبى,طاهرمحسن, العامرى,صالح مهدى, 2010, ص46).

ومن خلال ما سبق عرضه من تعريفات تناولت تحديد هوية الشفافية الإدارية يمكن للباحث أن يضع تعريفاً إجرائيا للشفافية الإدارية يتواكب مع الدراسة الراهنة فيما يلى: أ- عملية يتم من خلالها توفير نظم معلومات فاعلة بمنظمات الخدمات الاجتماعية. 
ب- تقوم على حق العاملين فى الحصول على المعلومات والبيانات بصورة صحيحة. ج- تؤدى إلى مشاركة فاعلة من العاملين بمنظمات الخدمات الاجتماعية فى اتخاذ القرارات الإدارية التى تخدم عمل المنظمة.

د- يستهدف تحقيقها إعلاء المصلحة العامة والتقويم المستمر وتطوير الأداء المؤسسى . هـ -تقوم على تتفيذ المسائلة والمحاسبية بين العاملين بالمنظمة على حد سواء. و - تتطلب البساطة والوضوح فى إجراءات العمل داخل المنظمة. 3- مفهوج الخدمات الاجتماعية

قبل ان نتتاول التعريفات التى حاولت تحديد هوية مفهوم الخدمات الاجتماعية يمكن

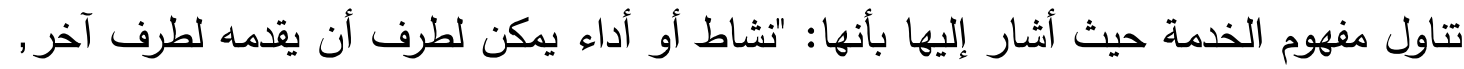

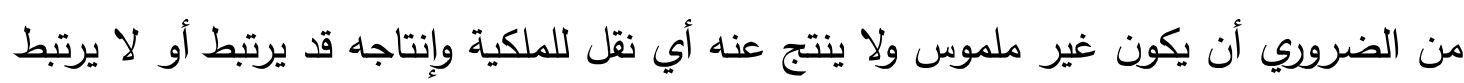
بالمنتج المادي". (Enquist, Edvardsson,2006,p23) كما تعرف الخدمة بأنها: “فعل أو أداء يمكن أن يقدمه طرف ما إلى طرف أخر يكون

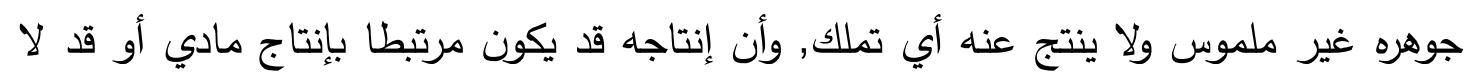

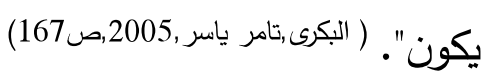

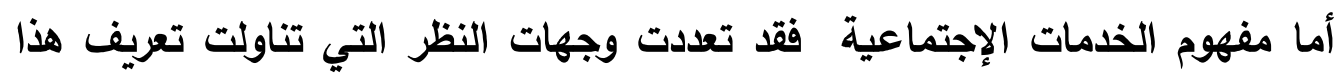

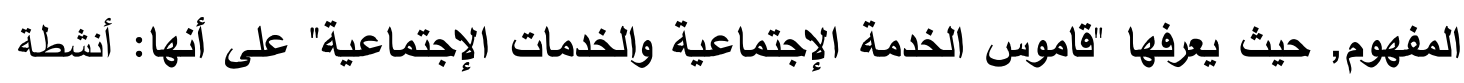

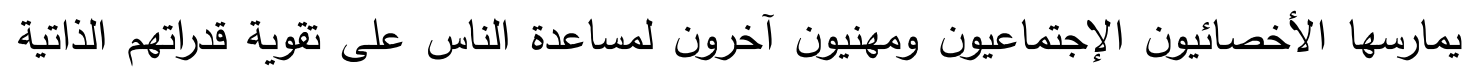

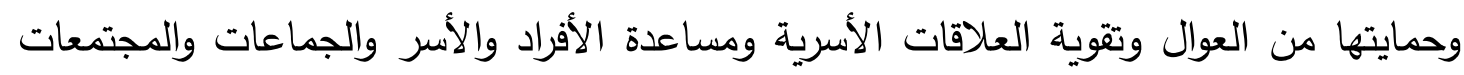

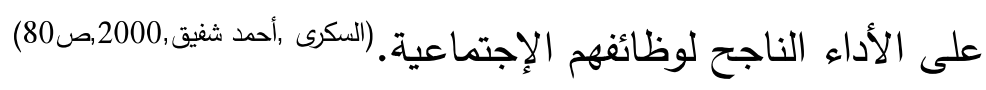
كما يعرفها"معجم مصطلحات العلوم الإجتماعة "نها: خدمات مهنية أو عمليات ومجهودات

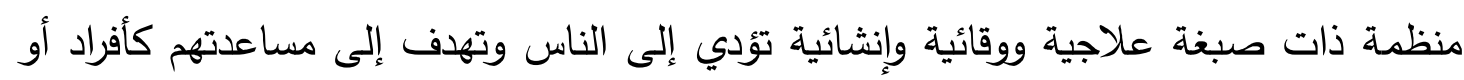

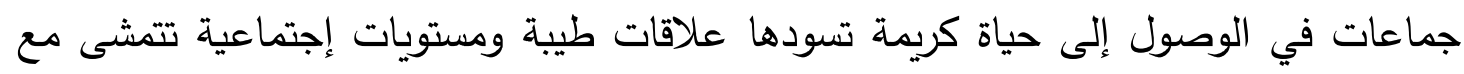

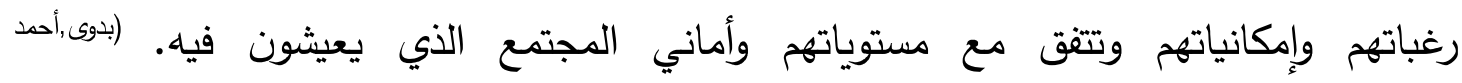


وعرفها أيضا " معجم مصطلحات العلوم الإجتماعة " بأنها: مجموعة الأنشطة التي يقوم بها

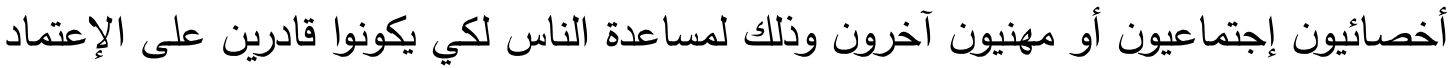
على أنفسه أو وقايتهم من الإتكالية على الآخرين, وكذلك مساعدتهم على تدعيم الروابط الإنط

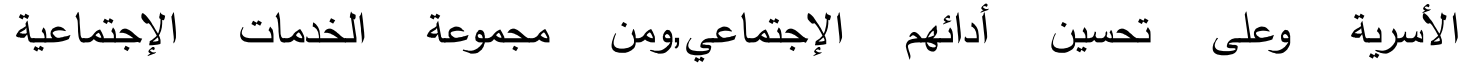

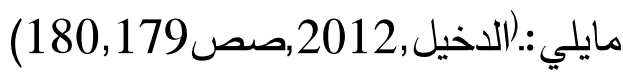
1- مساعدة الناس للحصول أو التعرف على المصادر الإقتصادية والمالية.

$$
\text { 2- 2 تقديم الإستشارات الإجتماعية. }
$$

3- القيام بتحويل العملاء كل حسب حاجته للمؤسسات الأخرى في المجتمع. 4- التوسط والدفاع عن العملاء متى كان ذلك ضروريا وممكنا. 5- تسهيل حصول العملاء على الخدمات وتعريفهم بالمؤسسات الموجودة بالمجتمع. وعُرفت الخدمات الإجتماعية بأنها:مجموعة الأنثطة التي يقدمها الأخصائيون الإجتماعيون بهاف تحسين المستوى المعيشي والصحي للناس,ولمساعدتهم على الاعتماد الذاتي والوقاية من الاعتماد على الآخرين وتقوية العلاقات الأسرية والمحافظة بنجاح على قيام الأفراد والأسر والجماعات والمجتمعات بوظائفهم الإجتماعية.

كما يمكن تعريف الخدمات الإجتماعية بأنها: تلك الجهود والبرامج التي تهدف إلى مساعدة

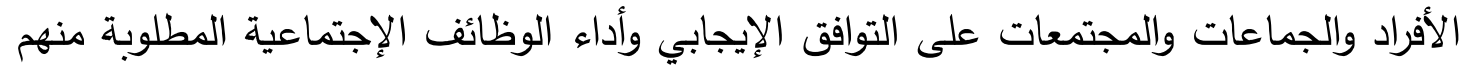

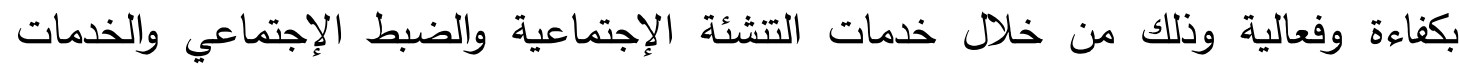

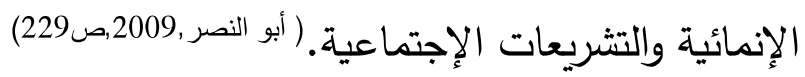

وفي هذا الصدد لابد أن تترابط الخدمات الإجتماعية فيما بينها وبين بعضها بحيث تخطط

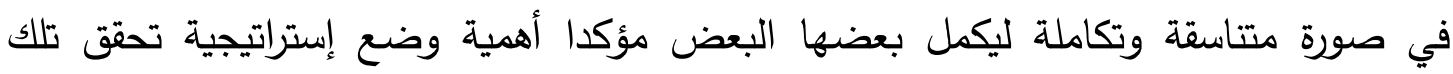

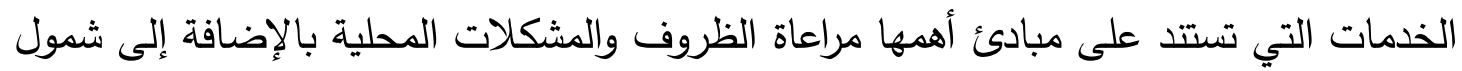

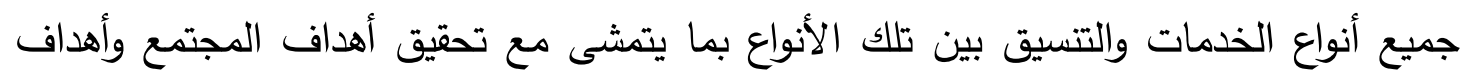
(أفراده.Pomanov ,Pave,2012,p14) و يعرفها" Alfred J. Khan " بأنها : مجموعة من الأنساق المحدة للرعاية الصحية

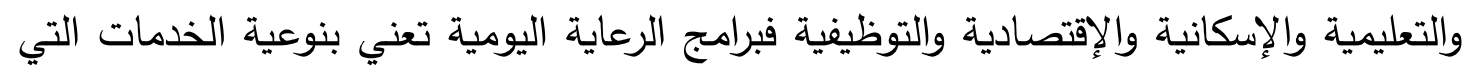

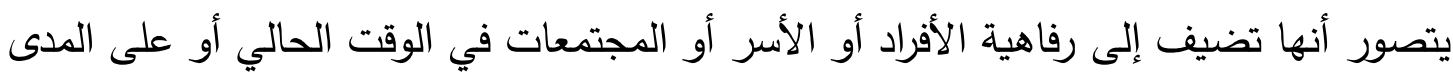


" Hugh Bochel and Et.el" ويرى كل من Khan,Alfred J.1983,p29 الطويل. الذدمات الإجتماعية أيضا أنها: تلك الأنثطة والبرامج والمشروعات المتعددة التي تقدمها المنظمات الإجتماعية لعملائها وذلك لإلشباع حاجاتهم الإجتماعية وحل مشكلاتهم الإجتماعية.(Bochel Hugh,Et.el,2005,p112, كما تعرف الخدمات الاجتماعية بأنها : مجموعة من الأنشطة التى يمارسها المختصون الاجتماعيون بهدف مساعدة الناس ليصبحوا

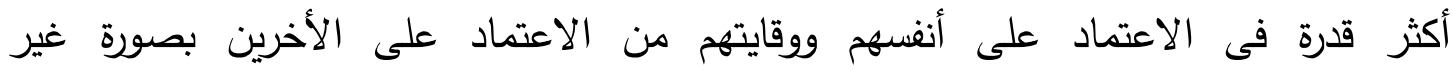

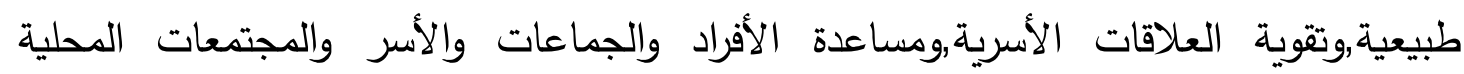

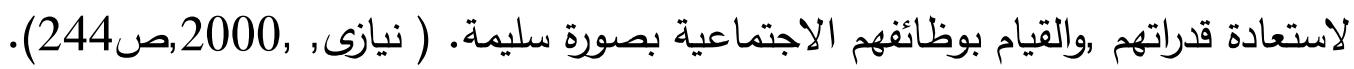

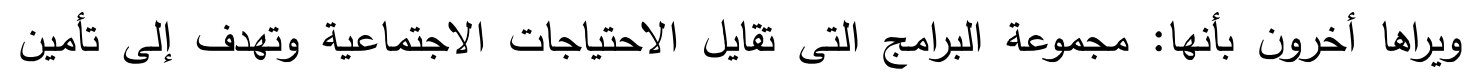

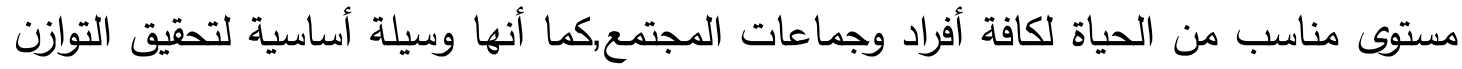

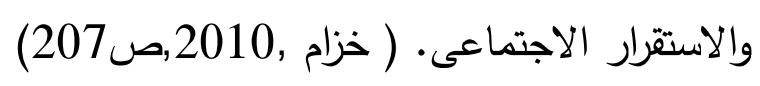
. مفهوم منظمات الخدمات الاجتماعية:

تعرف المنظمات بأنها:وحدات اجتماعية ذات غائماعية تسعى إليهاربمعنى أخر فهى

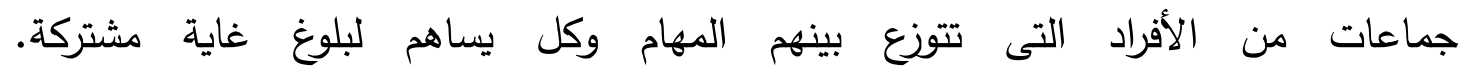
(ناجى, 18,17)

مفهوم المنظمة يعني " كيان منظم يهدف لتحقيق أغراض معينة ويتمتع بشخصية معنوية

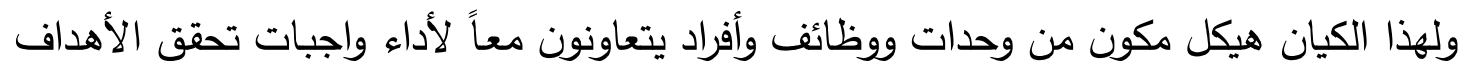

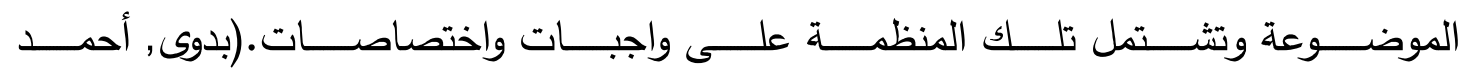

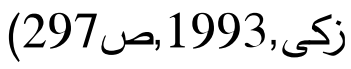

كما أن المنظمات تعد بمثابة هي كيانات أو وحدات اجتماعية تُنى لتحقيق أهداف معينة

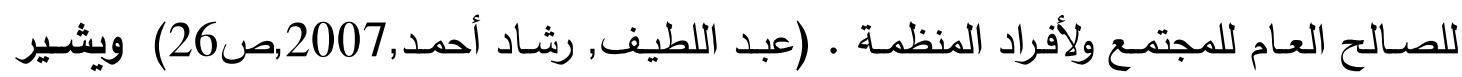

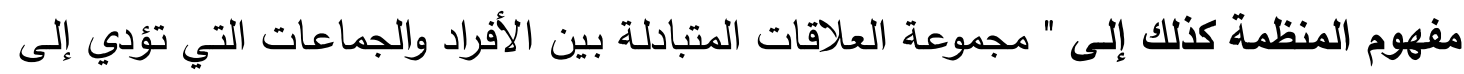

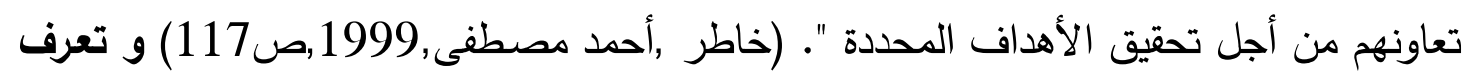

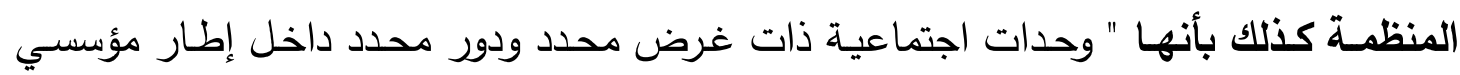

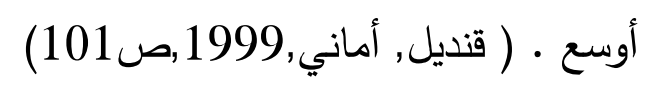

وتعرف علي أنها "وحدات إجتماعية أنشئت بغرض تحقيق أهداف محددة". (المغربي ,عبد

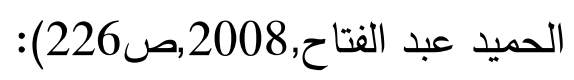


ويمكن وضـع تعريفاً إجرائيا لمنظمات الخدمات الاجتماعية يتتاسب مـع طبيعة الدراسـة الراهنـة فيما يلى

1- بناء يتكون من وحدات إجتماعية مرتبطة بنائياً ووظيفياً. 2- تقوم من أجل إنتاج سلعة أو تقديم خدمة لتحقيق أهداف معينة..

3- هى أداة إجتماعية تهدف إلى مساعدة الإنسان على مواجهة وحل المشكلات المتصلة بحياته داخل المجتمع الذي يعيشون فيه.

4- تمارس من خلاله الإدارة الأبعاد الأساسية لعملية الشفافية الإدارية كالإتصال والمسائلة والمحاسبية.

$$
\text { 5- تقوم على الإستثمار الأمثل للموارد (المادية- البشرية- التنظيمية). }
$$

6- تمارس عدداً من الأنشطة والعمليات التي تحقق أهدافها التتموية المنشودة. 7- تقوم بعملية تقييم ذاتي لجهودها وأعمالها بصورة متكررة ومستمرة. 8- تهدف إلى زيادة عاملي الكفاءة والرشد في إشباع الحاجات المتعددة للمجتمع. 9- تعتمد على بيئتها من أجل الحصول على الموارد والفرص الضرورية لوجودها.

\section{وحتى تتجح منظمات الخدمات الإجتماعية ، لابد أن يتوافر فيها الثروط التالية:-}

1-أن تعمل المنظمة على إحداث التوافق الإجتماعي بين أفراد المنظمة. 2-أن يكون إنشاء المنظمة لمواجهة حاجة أساسية في المجتمع.

3-أن يكون لدى المنظمة الحساسية اللازمة لإستشعار إحتياجات المجتمع للعمل على إثباعها. 4-أن تسمح نظمها بالإنفتاح على المجتمع 5- أن يتوفر في المنظمة نظام جيد للإتصالات والعلاقات العامة. 6- أن يتوفر في المنظمة سياسة مناسبة وعادلة للأجور ، والحوافز ، والتدريب ، والإشراف ، والتوجيه. ((محمد,ابراهيم عبدالهادى, 2000,ص251) 


\section{سادساً:المنطلقات النظربة للاراسة}

تنطلق الدراسة الراهنة من موجه نظرى تمثل فى نظرية النظمات الاجتماعية والتى بدأ الاهتمام بها يتزايد بعد الكساد الكبير الذي شهدته الإقتصاديات الغربية في بداية الثلاثينات، حيث ظهر قصور واضح في إدارة المنظمات كان من بين أسبابه الرئيسية عدم دراسة وفهم طبيعة العنصر الإنساني، المنظمة وفهم المتغيرات المؤثرة فيها

كما تصاعد الإهتمام بتطوير نظرية المنظمة،فقد تزايدات التوجهات العلمية لدراسة الفرد وعلاقته المتفاعلة مع الجماعات الصغيرة من خلال المنافع التي أخذت تتحقق بسبب التكامل الحي بين أوجه نشاط الفرد والجماعة في تحسين وتطوير عمل المنظمات والإنعكاسات الإيجابية لذلك في تطوير المجتمع ككل بإعتباره منظمة كبيرة تتفاعل وتتكامل فيها العلاقات الإنسانية وأصبح البحث في المنظمة حقلا علميا يتسم بالحركة والتعقيد لأن المجتمعات الإنسانية أصبحت أكثر تعقيدا وأسرع تطورا من أي وقت مضى. ( ( شمعان,خليل محمد , حمود خضير كامل,2007,صص

والمنظمات فى ضوء النظرية تمثل ضرورة أوجدتها الحاجة إليها لمقابلة إحتياجات الناس، ولقد إزداد عدد المنظمات في المجتمع الحديث بالدرجة التي أصبح يطلق عليه بحق مجتمع المنظمات، يث يعني هذا بأن أعضاء المجتمع أصبح بمقدورهم قضاء وإشباع إحتياجاتهم من خلال المنظمات . تلعب نظرية المنظمة دورًا مميزًا في الإرتقاء بعمل المنظمات من خلال تطويرها لأساليب وآليات مفردات عمل المنظمة وعناصرها، ويتجلى ذلك الدور بمهام دراسة تصميم المنظمة وتغييرها ودراسة الثقافة التظظيمية وما تتطلبه من تركيب تتظيمي.

\section{سابعاً:الإجراءات المنهجية للارراسة}

1- نوع الدراسة:تتدرج الدراسة الحالية تحت نمط الدراسات الوصفية التحليلية التي تستهدف وصف وتحليل ظاهرة معينة,حيث تستهدف وصف وتحليل واقع تطبيق الثفافية الإداريتبمنظمات الخدمات الاجتماعية,فى ضوء مؤشراتها الأساسية,للتوصل إلى مجموعة من المؤشرات التخطيطية التى يمكن أن تسهم فى تفعيل تطبيقها بهذه المنظمات.

2- المنهج المستخدم:إتساقاً مع نوع الدراسة الحالية,إعتمد الباحث على كل من المنهج الكي والكيفي بإستخدام المسح الإجتماعي الثامل للعاملين بالإدارات والأقسام التابعة لمديرية التضامن الاجتماعى بالفيوم. 
( أ ) المجال المكاني:تمثل المجال المكاني للدراسة الحالية فى مديرية التضامن الاجتماعى بالفيوم (ب) المجال البثري:حصر شامل لجميع العاملين بالإدارات والأقسام المختلفة التابعة لمديرية التضامن الاجتماعى بالفيوم,حيث بلغ عددهم (278) مفردة, من خلال (17) إدارة وقسم والجدول التالى يوضتح إطار المعاينة:.

جدول رقم) (1) - (1) - (1)

يوضتح إطار المعاينة للمبحوثين (مجتمع البحث)

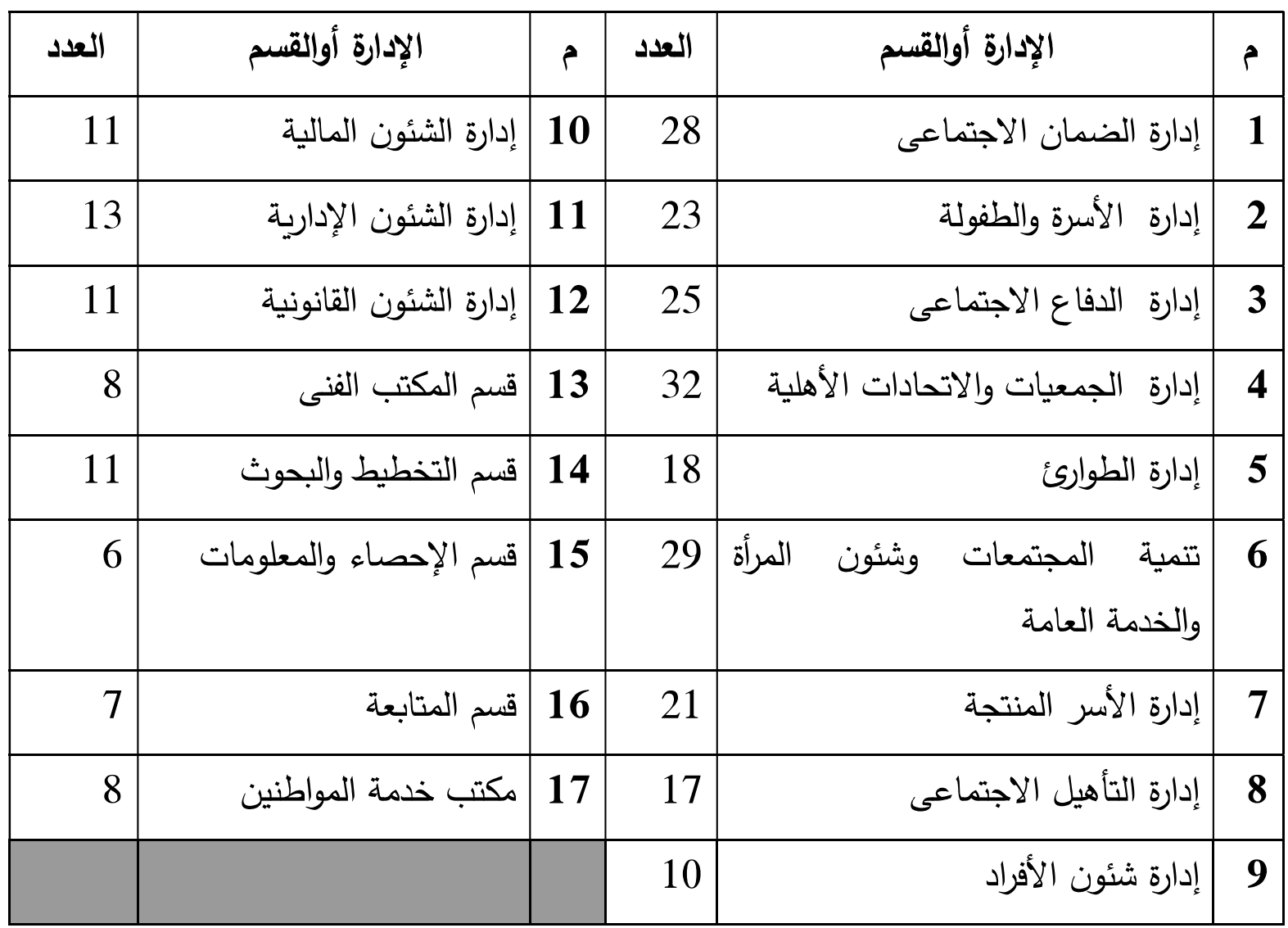

(ج) المجال الزمني:تمثل في فترة جمع البيانات من الميدان وتحليلها وتفسيرهاروهي الفترة الزمنية من 2020/10/9 إلى 2020/12/8.

أدوات الدراسة:إتساقا مع متطلبات الدراسة الراهنة فقد إعتمد الباحث على الأدوات التالية: 
أدوات جمع البيانات:- قام الباحث في هذه الدراسة بتصميم إستمارة قياس مطبقة على العاملين بمديرية التضامن الاجتماعى بالفيوم,حيث إشتملت على البيانات الأولية وأبعاد الثفافية الإدارية,حيث تم تحديد هذه الأبعاد فيما يلى : بلى

البعد الأول : واقع تطبيق الثفافية الإدارية فى ضوء نظم المعلومات بمنظمات الخدمات الاجتماعية,وقد إحتوى البعد على (11عبارة ). البع الثانى : واقع تطبيق الثفافية الإدارية فى ضوء نمط الاتصال القائم بمنظمات الخدمات الاجتماعية, وقد إشتمل المؤشر على (9 عبارات ). البعد الثالث : واقع تطبيق الثفافية الإدارية فى ضوء المسائلة والمحاسبية بمنظمات الخدمات الاجتماعية., وقد إثتمل المؤشر على ( 9 عبارات ). البعد الرابع: واقع تطبيق الثفافية الإدارية فى ضوء مشاركة العاملين فى اتخاذ القرارات بمنظمات الخدمات الاجتماعية,وقد إشتمل المؤشر على ( 10عبارات ). البعد الخامس: واقع تطبيق الثفافية الإدارية فى ضوء اللوائح والإجراءات بمنظمات الخدمات الاجتماعية, وقد إشتمل المؤشر على ( 12 عبارة ). ـ معوقات تطبيق الثفافية الإدارية بمنظمات الخدمات الاجتماعية.وبلغت عباراتها(20 عبارة) ـ مقترحات لتفعيل تطبيق الثفافية الإدارية بمنظمات الخدمات الاجتماعية الأهلية. وتم تصميم إستمارة القياس وفقاً للخطوات التالية:-* الإستفادة من التراث النظري المرتبط بموضوع الدراسة,والإطار التصورى النظرى الموجه للدراسة,وكذا الدراسات السابقة ذات الصلة,إلى جانب إستفادة الباحث من بعض المقاييس ذات الصلة بموضوع الدراسة,مما ساهم في تحديدعبارات إستمارة القياس. مرحلة صدق وثبات أداة القياس :

أولاً :. صدق الأداة: فى ضوء الأهمية التى تمثلها خطوة صدق الآداة,استخدم الباحث الصدق الظاهري وذلك بعرض أداة القياس على (12) أستاذ من أساتذة الخدمة الاجتماعية بكل من كلية الخدمة الاجتماعية جامعة حلوان,وكلية الخدمة الاجتماعية جامعة الفيوم لإبداء الرأى فى صلاحية أداة القياس،من حيث السلامة اللغوية للعبارات وإرتباطها بأبعاد الدراسة ومتغيراتها مع إجراء التعديلات عليها،وبناءً على ذلك تم تعديل وإضافة وحذف بعض العبارات وفقاً لدرجة اتفاق 
لا تقل عن(80\%) وفى نهاية المرحلة تم وضع أداة القياس فى صورتها النهائية.حيث بلغ الصدق الظاهري للأداة (84.7\% ) وذلك بعد استبعاد العبارات المكرة والمرفوضة نهائيا. كما إعتمد الباحث على صدق الإتساق الداخلى،وذلك بحساب معامل الإرتباط بين درجة كل بُعد من أبعاد آداة القياس والدرجة الكلية لها،بعد تطبيق أداة القياس على عينة قوامها( 10 ) من العاملين بالإدارات والأقسام المختلفة بمديرية التضامن الاجتماعى ببنى سويف,لها نفس خصائص وسمات وشروط العينة الأصلية (مجتمع البحث)،وجاءت النتائج كالتالى:

$$
\text { جدول رقم (2 ) - (2) }
$$

يوضت العلاقة الإرتباطية بين درجة كل بُعد من أبعاد المقياس والدرجة الكلية للمقياس

\begin{tabular}{|c|c|}
\hline المقياس ككل & أبعاد المقياس \\
\hline 0.811 & واقع تطبيق الشفافية الإدارية فى ضوء نظم المعلومات \\
\hline 0.829 & : واقع تطبيق الشفافية الإدارية فى ضوء نمط الاتصال القائم \\
\hline 0.801 & واقع تطبيق الشفافية الإدارية فى ضوء المسائلة والمحاسبية \\
\hline 0.833 & واقع تطبيق الشفافية الإدارية فى ضوء مشاركة العاملين \\
\hline 0.861 & واقع تطبيق الثفافية الإدارية فى ضوء اللوائح والإجراءات \\
\hline 0.897 & معوقات تطبيق الثفافية الإدارية بمنظمات الخدمات الاجتماعية الأهلية \\
\hline 0.822 & قيمة المعاملات الإرتباطية لآداة القياس ككل \\
\hline
\end{tabular}

$$
0.05 \text { معنوية عند }
$$

ويتضح من نتائج الجدول السابق أن معاملات الإرتباط مقبولة ودالة إحصائياً مما يدل على صدق الإتساق الداخلى لأداة القياس.

ثانياً: ـ ثبات أداة القياس:اعتمد الباحث فى التأكد من ثبات أداة القياس على طريقة إعادة الاختبار كطريقة من الطرق الإحصائية لقياس الثبات,وذلك بتطبيق أداة القياس على عينة من 
المبحوثين بلغ قوامها (10) من العاملين بالإدارات والأقسام المختلفة بمديرية التضامن

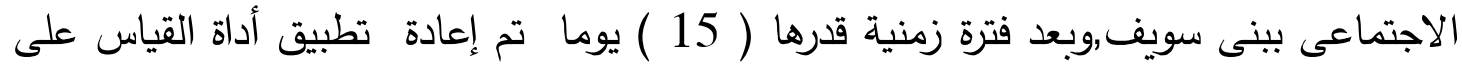
نفس العينة,وتم استخراج النتائج مع المقارنة بين إستجابات كل من الاختبارين وحساب معامل

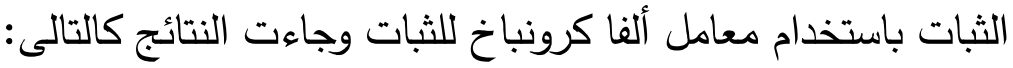

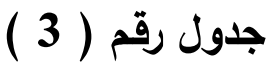

يوضح ثبات أداة القياس بإستخدام معامل ألفا كرونباخ للثبات

\begin{tabular}{|c|c|c|}
\hline 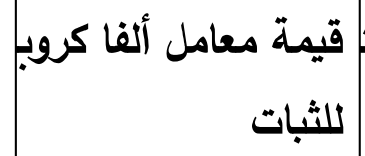 & عددالعبارات & البعد \\
\hline 0.801 & 11 & واقع تطبيق الثفافية الإدارية فى ضوء نظم المعلومات \\
\hline 0.811 & 9 & : واقع تطبيق الشفافية الإدارية فى ضوء نمط الاتصال القائم \\
\hline 0.847 & 9 & واقع تطبيق الثفافية الإدارية فى ضوء المسائلة والدحاسبية \\
\hline 0.769 & 10 & واقع تطبيق الثفافية الإدارية فى ضوء مشاركة العاملين فى اتخاذ القرار \\
\hline 0.799 & 12 & واقع تطبيق الثفافية الإدارية فى ضوء اللوائح والإجراءات وأليات العمل \\
\hline 0.888 & 20 & معوقات تطبيق الثفافية الإدارية بنظمات الخدمات الاجتماعية \\
\hline 0.842 & 71 & 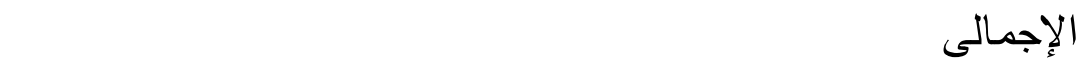 \\
\hline
\end{tabular}

يتضح من خلا الجدول السابق أن قيمة معامل ألفا كرونباخ للثبات لكل بعد من أبعاد أداة القياس مرتفعة،وأن قيمته للأداة ككل =( 0.842) مما يدل على ثبات لقدل أداة القياس، والإعتماد عليها.

(ب)(أساليب التحليل الإحصائى:إعتمد الباحث على إستخدام التكرارات والنسب المئوية والأوزان المرجحة وترتيب العبارات , والمتوسط الحسابى للحكم على واقع ممارسة الثفافية الإدارية بمنظمات الخدمات الاجتماعية فى ضوء مؤشراتها الأساسية بحيث تكون بداية ونهاية فئات إداة القياس الثلاثية نعم(3 درجات),إلى حدما(درجتان),لا(درجة واحدة),وترميز وإدخال البيانات على فئل 
الحاسب الآلى ,مع تحديد الحد الأعلى والأدنى,وكذلك مستويات المتوسطات الحسابية,حيث يتضح ذلك من خلال الجدول التالى:.

\section{جدول رقم (4) \\ يوضح مستويات المتوسطات الحسابية}

\begin{tabular}{|c|c|}
\hline مستوى منخفض & إذا تراوحت قيمة المتوسط للعبارة أو البعد من 1 إلى أقل من 1,67 \\
\hline مستوى متوسط & إذا تراوحت قيمة المتوسط للعبارة أو البعد من 67,1إلى أقل من 2,35 \\
\hline 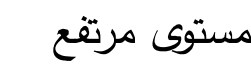 & إذا تراوحت قيمة المتوسط للعبارة أو البعد من 2,35إلى أقل من 3 \\
\hline
\end{tabular}

وتم في ضوء ذلك تحليل البيانات بما يتتاسب مع أهداف الدراسة وتساؤلاتها.

ثامناً: نتائج الدراسة الميدانية وتفسيرها

$$
\text { (أ) - وصف مجتمع الدراسة:- }
$$

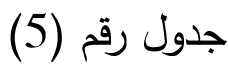

يوضح خصائص المبحوثين من العاملين بمنظمات الخدمات الاجتماعية (مجتمع الدراسة)

$(278=\dot{0})$

\begin{tabular}{|c|c|c|c|}
\hline النسبة المئوية (\%) & 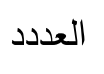 & |البيان & المتغيرات \\
\hline$\% 57.19$ & 159 & ذأكر & \multirow{3}{*}{ النوع } \\
\hline$\% 42.81$ & 119 & |نثي & \\
\hline$\% 100$ & 278 & |أجمالي & \\
\hline$\% 10.43$ & 29 & |أقل من 30 سنة & \multirow{5}{*}{ 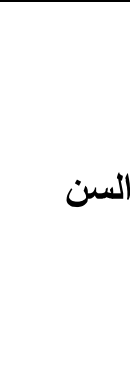 } \\
\hline$\% 31.65$ & 88 & 30 لأقل من 40 سنة & \\
\hline$\% 39.57$ & 110 & 40 لأقل من 50 سنة & \\
\hline$\% 18.35$ & 51 & 50 لأقل من 60 سنة & \\
\hline$\% 100$ & 278 & |جمالي & \\
\hline$\% 14.03$ & 39 & مؤهل متوسط & \multirow{3}{*}{ الحالة التعليه } \\
\hline$\% 11.14$ & 31 & مؤهل فوق متوسط & \\
\hline$\% 63.31$ & 176 & |مؤهل جامعى & \\
\hline
\end{tabular}


مجلة كلية الخدمة الاجتماعية للار اسات و البحوث الاجتماعية - جامعة الفيوم

\begin{tabular}{|c|c|c|c|}
\hline$\% 5.02$ & 14 & ماجستير & \\
\hline$\% 6.47$ & 18 & دكتوراة & \\
\hline$\% 100$ & 278 & |اجمالي & \\
\hline$\% 14.76$ & 41 & |اعزب & \multirow{5}{*}{ الحالة الإجتماعية } \\
\hline$\% 75.89$ & 211 & متزوج & \\
\hline$\% 7.55$ & 21 & |أرمل & \\
\hline$\% 1.80$ & 5 & مطلق & \\
\hline$\% 100$ & 278 & |جمالي & \\
\hline$\% 0.36$ & 1 & مدير عام & \multirow{5}{*}{ الوظيفة بالمنظمة } \\
\hline$\% 6.12$ & 17 & مدير إدارة & \\
\hline$\% 9.71$ & 27 & رئيس قسم & \\
\hline$\% 83.81$ & 233 & موظف & \\
\hline$\% 100$ & 278 & |جمالي & \\
\hline$\% 24.10$ & 67 & |أقل من 5 سنوات & \multirow{5}{*}{ مدة العمل بالمنظمة } \\
\hline$\% 26.62$ & 74 & من 5 سنوات لأقل من 10 & \\
\hline$\% 29.14$ & 81 & من 10 سنوات لأقل من 15 سنة & \\
\hline$\% 20.14$ & 56 & 15 سنة فأكثر & \\
\hline$\% 100$ & 278 & |جمالي & \\
\hline$\% 11.87$ & 33 & أقل من 5 سنوات & \multirow{6}{*}{ عدد سنوات الخبرة في مجال } \\
\hline$\% 42.09$ & 117 & سنوات 5 سنوات لأقل من 10 & \\
\hline$\% 22.30$ & 62 & من 10 سنوات لأقل من & \\
\hline$\% 6.83$ & 19 & من 15 سنة لأقل من 20 & \\
\hline$\% 16.91$ & 47 & 20 سنة فأكثر & \\
\hline$\% 100$ & 278 & |جمالي & \\
\hline
\end{tabular}

بإستقراء بيانات الجدول السابق يتضح ما يلى:. 
ـ أن العاملين بمنظمات الخدمات الاجتماعية(مجتمع البحث) يتوزعون وفق متغير النوع حيث بلغت نسبة الذكور (57.19\%) من الذكور بيينما نسبة (42.81\%) من الإناث.

. أظهرت بيانات الجدول توزيع مجتمع البحث وفقا للسن,حيث إتضح أن غالبية العاملين

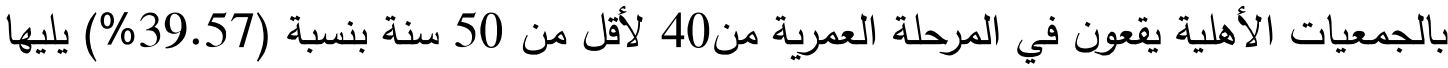

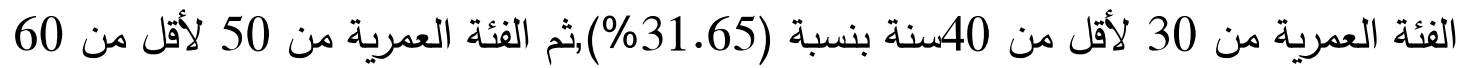
سنة بنسبة (18.35\%) ويلها الفئة العرية أقل من 30 سنة بنسبة (10.43\%) ـ أظهرت نتائج نفس الجدول أن غاليبة العاملين بمنظمات الخدمات الاجتماعية(مجتمع البحث) من الحاصلين على مؤهل جامعى(ليسانس أو بكالوريوس) حيث بلغت نسبتهم (63.31\%)ريلين بلئهم الحاصلين على مؤهلات متوسطة بنسبة (14.03\%),ثم الحاصلين على مؤهل فوق متوسط, بنسبة (11.14\%),يليها وبنسبة(6.47\%) من الحاصلين على درجة الدكتوراة وأخيرا بلغت نسبة عولية

$$
\text { الحاصلين على درجة الماجستير (5.02\%). }
$$

ـ يتضح من خلال بيانات الجدول السابق أن نسبة(15,89\%)من العاملين بمنظمات الخدمات

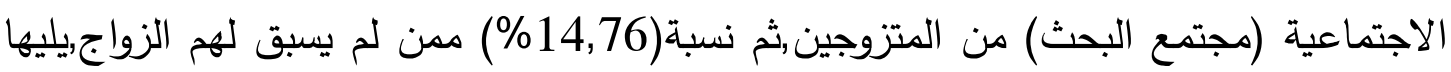

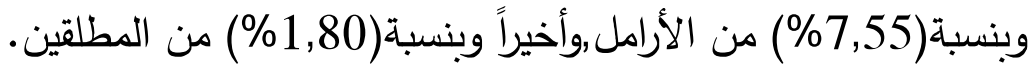

ـ يتضح من بيانات الجدول السابق أن الأغلبية من مجتمع البحث تتوزع وفقا للهيكل الوظيفي

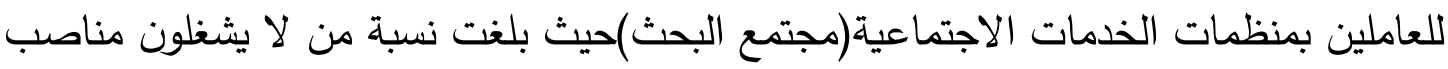

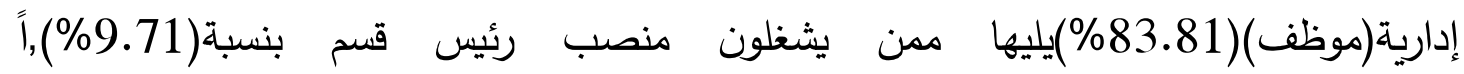
نسبة(6.12\%)وأخيراً ممن يشغلون منصب مدير إدارة بالمنظمة,وبنسبة(0.36\%)ممن يشغلون

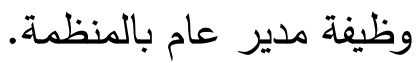
. يتضح من الجدول السابق أن نسبة (29.14\%) ممن تمثل مدة عملهم بالمنظمة من 10 من سنوات لأقل من 15 سنة,يليها ممن تتمثل سنوات العمل بالمنظمة من 5 سنوات لأقل من 10

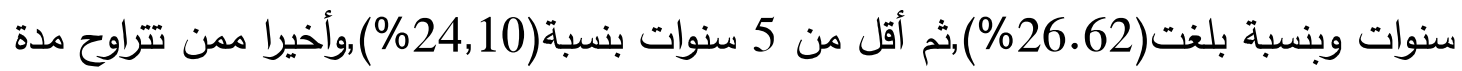
العمل بالمنظمة 15سنة فأكثر بنسبة بلغت(20.14\%) ـ يتبين من الجدول السابق توزيع مجتمع البحث وفقا لسنوات خبرتهم في العمل بمجال الخدمات الاجتماعية حيث بلغت نسبة(42.09\%) من العينة ممن تمثلت خبرتهم في العمل فى مجال الخدمات الاجتماعية من 5 سنوات لأقل من 10 سنوات,ثم من 10 سنوات لأقل من 15سنة 
بنسبة(22.30\%),يليها ممن تتمثل مدة خبرتهم20سنة فأكثر بنسبة(16.91\%), ثم أقل من 5

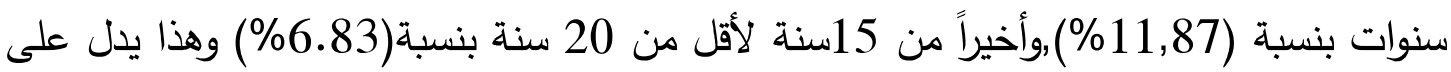
أن أغلبية العاملين (مجتمع البحث) لديهم الخبرة المتوسطة والتى يمكن أن تؤهلهم للعمل ومن ثم المساهمة فى تحقيق أهداف المنظمة.

2-2 النتائج الجدولية المرتبطة بواقع تطيق الثفافية الإدارية بمنظمات الخدمات الاجتماعية : أ- النتائج الجدولية المرتبطة بواقع تطبيق الثفافية الإدارية فى ضوء نظم المعلومات ذ

جدول رقم (6)

يوضح واقع تطبيق الثفافية الإدارية فى ضوء نظم المعلومات من وجهة نظر العاملين (278 = ن (ن)

بمنظمات الخدات الاجتماعية (مجتمع البحث)

\begin{tabular}{|c|c|c|c|c|c|c|c|}
\hline \multirow[b]{2}{*}{ 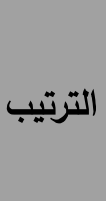 } & \multirow{2}{*}{$\begin{array}{l}\text { النسبية } \\
\text { القوة } \\
\end{array}$} & \multirow{2}{*}{ ال المرحج } & $y$ & إلى حـ ما & نعم & \multirow[b]{2}{*}{ 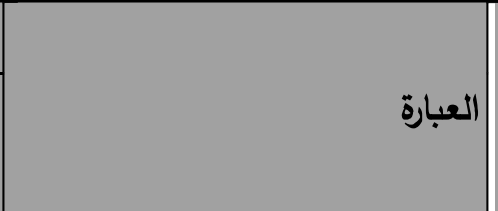 } & \\
\hline & & & ك & ك & ك & & \\
\hline 9 & 74.94 & 625 & 88 & 33 & 157 & [فى عرض الإدارة على علدم المبالغة & 1 \\
\hline 8 & 77.22 & 644 & 78 & 64 & 146 & | اللازومة لأداء مهام عملين المطومات والبيانات. & 2 \\
\hline 5 & 83.81 & 699 & 55 & 55 & 178 & بالدقة. & 3 \\
\hline 3 & 85.61 & 714 & 39 & 42 & 197 & 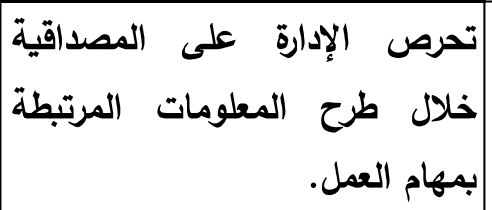 & 4 \\
\hline 7 & 77.58 & 647 & 69 & 49 & 160 & تبعمل المنظمة. الإدارة المعلومات الخاصة & 5 \\
\hline 11 & 71.94 & 600 & 88 & 58 & 132 & |المبنظمة. & 6 \\
\hline 6 & 82.97 & 692 & 38 & 66 & 174 & 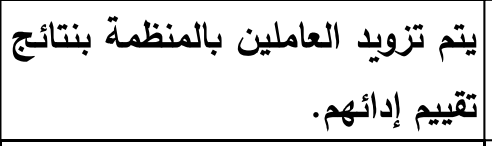 & 7 \\
\hline 4 & 85.25 & 711 & 32 & 59 & 187 & تحرص الإدارةعلى توفير وسائل & 8 \\
\hline
\end{tabular}




\begin{tabular}{|c|c|c|c|c|c|c|c|}
\hline \multirow[b]{2}{*}{ |الترتيب } & \multirow{2}{*}{$\begin{array}{l}\text { القوبية } \\
\text { النسبية }\end{array}$} & \multirow{2}{*}{ المرحج التكرار } & $y$ & إلى حد ما & نعم & \multirow[b]{2}{*}{ |العبارة } & \\
\hline & & & ك5 & كs & ك5 & & 2 \\
\hline & & & & & & |العمل. تكنولوجيا المعلومات اللازمة لمهام & \\
\hline 1 & 89.33 & 745 & 22 & 45 & 211 & | مهامهم. & 9 \\
\hline 2 & 88.73 & 740 & 17 & 60 & 201 & |لجميع العاملين بالمنظمة المعلومات المالية & 10 \\
\hline 10 & 73.26 & 611 & 94 & 35 & 149 & |تحدد الإدارة أهداف عمل المنظمة & 11 \\
\hline القنبية & الحسابي المتوسط & التكرارات & 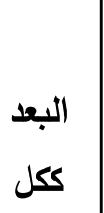 & & & & \\
\hline 80.97 & 675.27 & 7428 & & & & & \\
\hline
\end{tabular}

يتضح من خلال بيانات الجدول (6)أن واقع تطبيق الثفافية الإدارية فى ضوء نظم المعلومات بمنظمات الخدمات الاجتماعية جاءت من وجهة نظر العاملين بمديرية التضامن الاجتماعى بالفيوم (مجتمع البحث),بقوة نسبية للبعد بلغت(80.97\%),وبمتوسط حسابى مرجح بلغ (675.27),مما ييدل على قوة رؤية المبحوثين.

حيث أثشار نسبة (89.33\%)إلـى أنـه " يـتم تـوفير المعلومـات للعـاملين فـى الوقت المناسب لتمكينهم من أداء مهامهم " وحصلت على الترتيب الأول من بين ترتيب العبارات,بينما

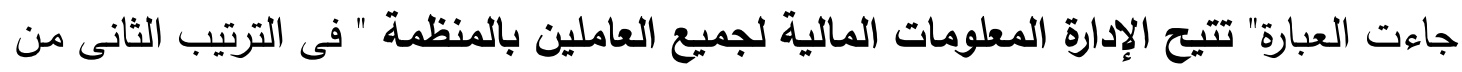

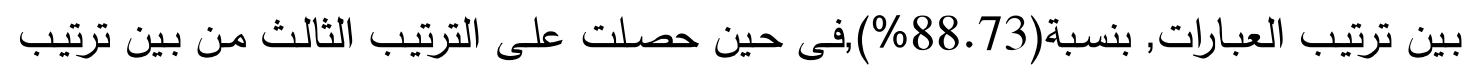

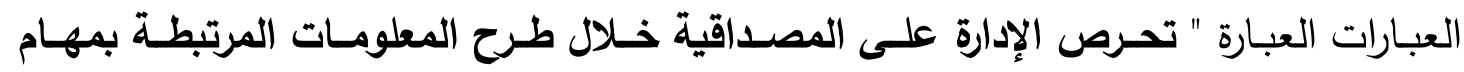
العمل. ,بنسبة بلغت(85.61\%), بينما أكدت نسبة(85.25\%)على " حرص الإدارةعلى توفير العصدي

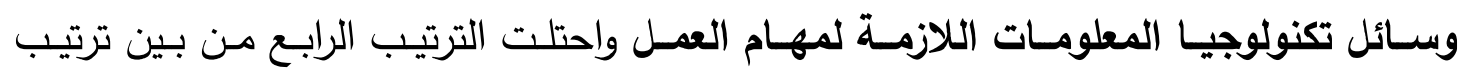

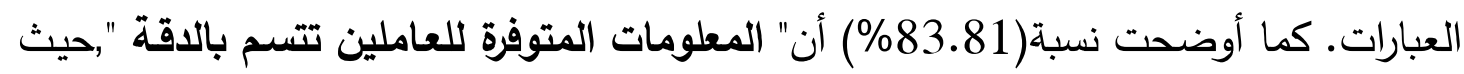
حصلت على الترتيب الخامس من بين ترتيب العبارات.فى حين أشارت نسبة (82.97\%) من 
نفس العينة إلى أنه " يتم تزويد العاملين بالمنظمة بنتائج تقييم إدائهم. ",وجاءت فى الترتيب السادس من بين ترتيب العبارات.بينما أكدت نسبة (77.58\%) على " تبين الإدارة المعلومـات الخاصــة بعــل المنظمـة. ",وإحتلـت الترتيـب السـابع مـن بـين ترتيـب العبارات بيينــا أشـارت نسبة(77.22\%) من عينـة الدراسـة إلى " يتوافر للعاملين المعلومـات والبيانـات اللازمـة لأداء مهام عملهم",وجاءت فى الترتيب الثامن من بين ترتيب العبارات,بينما أكدت نسبة(74.94\%) من مجتمع البحث على " حرص الإدارة على عدم المبالغة فى عرض الحقائق على العاملين ",وحصلت على الترتيب التاسع من بين ترتيب العبارات,فى حين حصلت العبارة " تحدد الإدارة أهداف عمل المنظمة وتعلنها كتابياً للعاملين ",على الترتيب العاشر من ترتيب العبارات,بنسبة بلغت (73.26\%) من مجتمع البحث, وأخيرا أشـارت نسبة(71.94\%) من عينة الدراسـة إلى " أحرص الإدارة على تعميم المعلومـات على جميع العـاملين بالمنظمـة ",وجاءت فى الترتيب الحادى عشر من بين ترتيب العبارات.

وبتحليل نتائج الجدول يتضح أن واقع تطبيق الشفافية الإدارية فى ضوء نظم المعلومات المتوفرة بمنظمات الخدمات الاجتماعية والتى تخدم عملها متوسط نسبياً وقد يرجع ذلك إلى أهمية توافر المعلومات والبيانات اللازمة والتى تتطلبها جودة الخدمات الاجتماعية بهذه المنظمات,ويتفق ذلك مع دراسة(Patrick,Villeneuve,2007) )والتى أشارت فى نتائجاها إلى أهمية الثفافية المعلوماتية فى تحقيق المنظمات لأهدافها التموية,نظراً لأنها ترتبط بكمية المعلومات المتاحة للعاملين بالمنظمة من ناحية وللجمهور المستفيد من خدماتها من ناحية أخرى,واوصت نفس الدراسة بضرورة إلزام المنظمات الخدمية بممارسة أكبر قدر من الشفافية

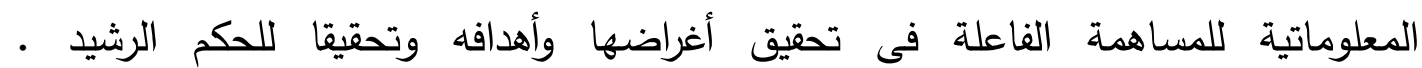
(Villeneuve,Patrick,2007,p147) 
جدول رقم (7) - (7) - (7)

يوضح واقع تطبيق الثفافية الإدارية فى ضوء نظام الاتصال القائم من وجهة نظر العاملين

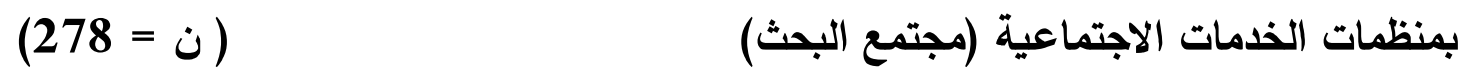

\begin{tabular}{|c|c|c|c|c|c|c|}
\hline الترتيب & القوة النسبية & المرحرج & $\frac{\gamma}{y}$ & إلى حـ ما & نعم & |العبارة \\
\hline 5 & $\% 79.14$ & 660 & 58 & 58 & 162 & قالعرات الصال فالدارة على فتح \\
\hline 6 & $\% 78.65$ & 656 & 71 & 36 & 171 & |تصال إدارى مناسبة بالمنظمة أساليب \\
\hline 3 & $\% 81.65$ & 681 & 55 & 43 & 180 & 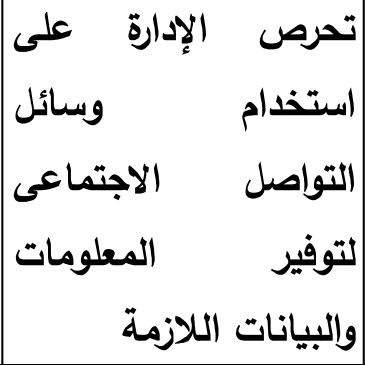 \\
\hline 9 & $\% 70.86$ & 591 & 84 & 75 & 119 & 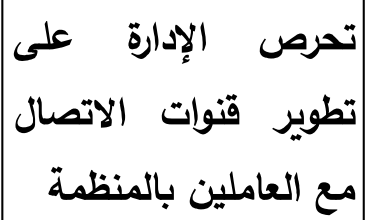 \\
\hline 1 & $\% 94.48$ & 788 & - & 46 & 232 & 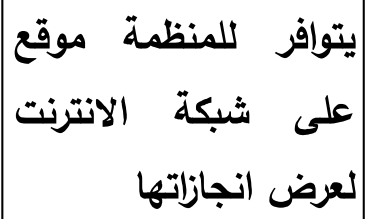 \\
\hline 8 & $\% 77.09$ & 643 & 64 & 63 & 151 & | \\
\hline 4 & $\% 79.86$ & 666 & 62 & 44 & 172 & |جمترص الادارة على عقد \\
\hline
\end{tabular}




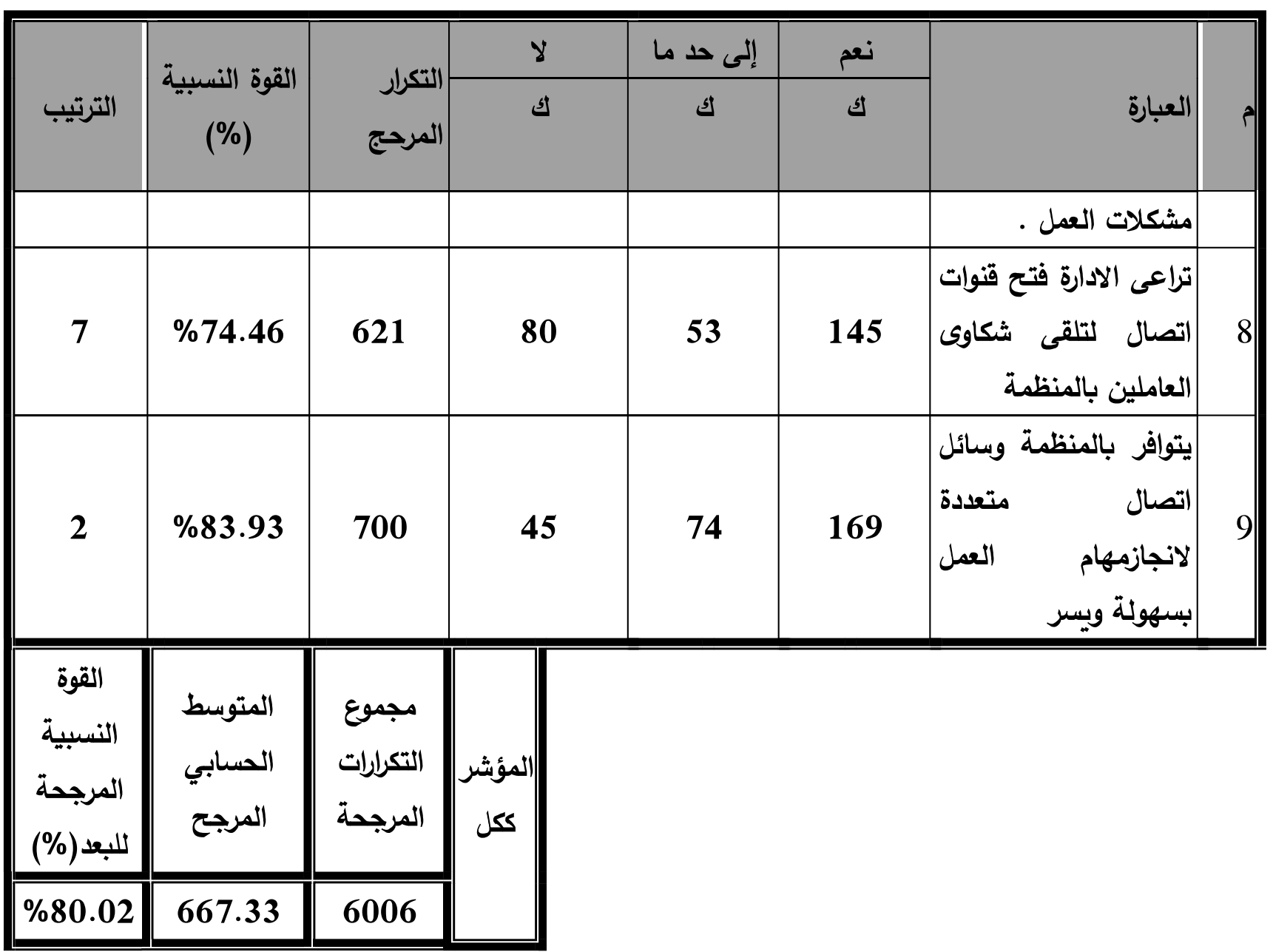

يتبين من خلال بيانات الجدول (7)أن واقع تطبيق الثفافية الإدارية فى ضوء نظام الاتصال القائم بمنظمات الخدمات الاجتماعية جاءت من وجهة نظر العاملين بديرية التضامن

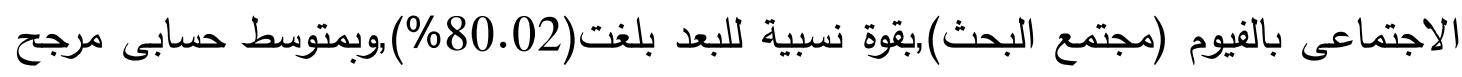
بلغ (667.33),مما ييدل على قوة رؤية المبحوثين.

حيث أشـار نسبة (94.48\%)إلـى أنـه " يتوافر للمنظمـة موقع على شبكة الانترنت

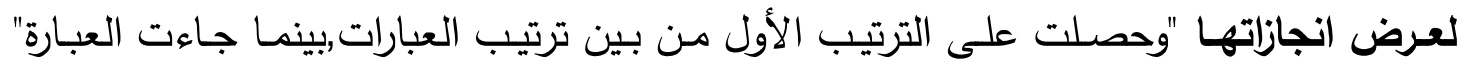

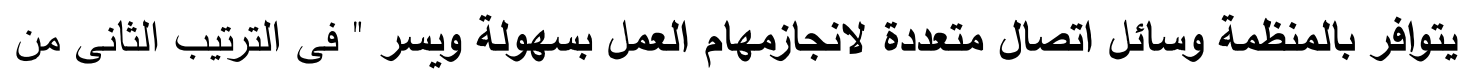

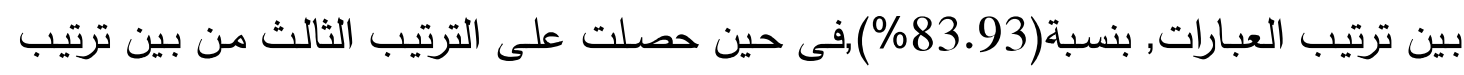
العبارات العبارة " تحرص الإدارة على استخلام وسـائل التواصل الاجتمـاعى لتوفير المعلومـات

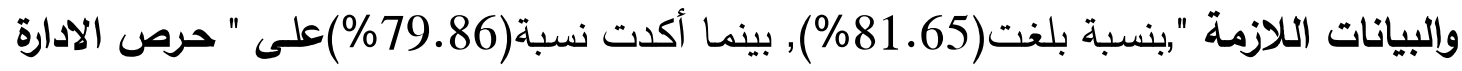

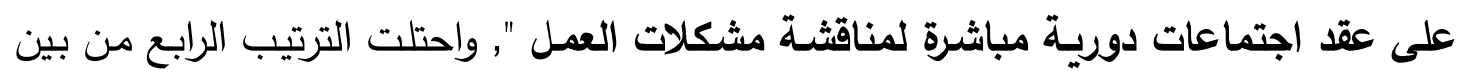


ترتيب العبارات. كما أوضحت نسبة(79.14\%) على" حرص الإدارة على فتح قنوات اتصال فاعلة مع العاملين بالمنظمة ",حيث حصلت على الترتيب الخامس من بين ترتيب العبارات.فى هرصى

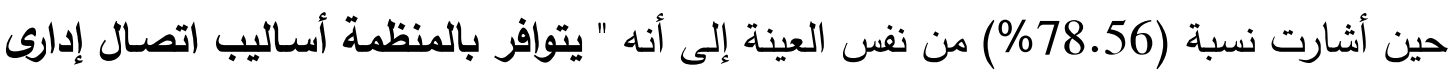

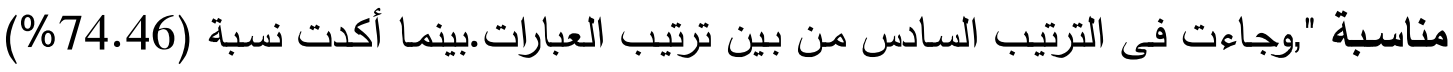

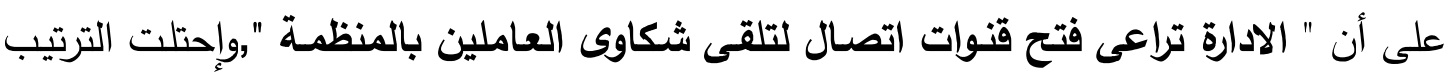
السابع من بين ترتيب العبارات,بينما أشارت نسبة(77.09\%) من عينة الدراسة إلى " استخدام العاملون وسائل الاتصال المباشرة مـع الادارة دون قيود ",وجاءت فى الترتيب الثامن من بين

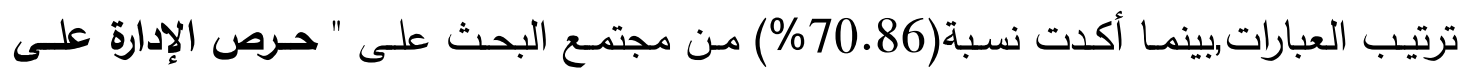

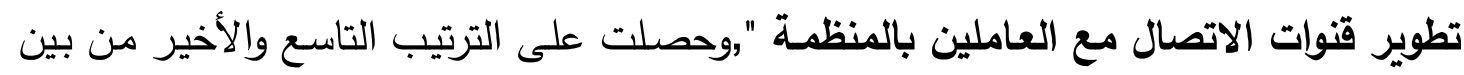

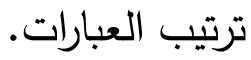

وبتحليل نتائج الجدول يتضح أن واقع تطبيق الثفافية الإدارية فى ضوء نظام التصال القائم مرتفع وقد يرجع ذلك إلى حرص الدولة على تععيل استخدام تكنولوجيا الاتصال

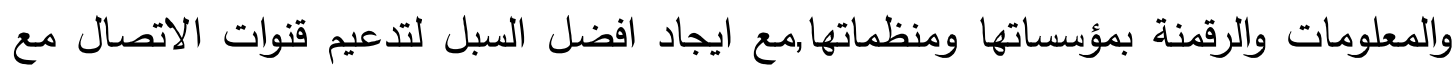

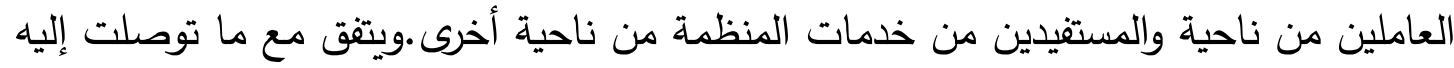

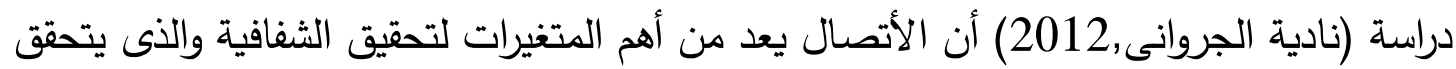

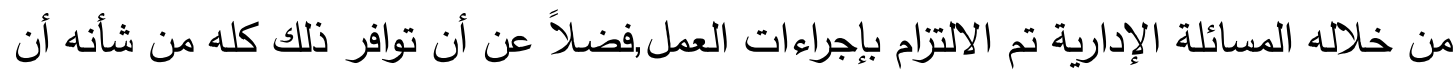

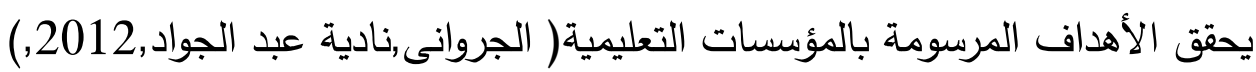


جدول رقم (8) - (2) - (2)

يوضح واقع تطبيق الثفافية الإدارية فى ضوء المسائلة والمحاسبية من وجهة نظر العاملين

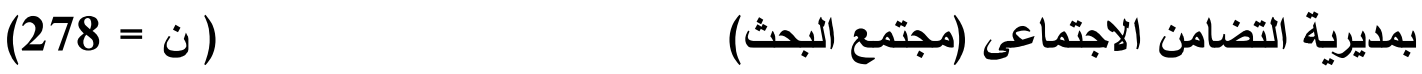

\begin{tabular}{|c|c|c|c|c|c|c|}
\hline \multirow[b]{2}{*}{ 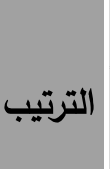 } & \multirow{2}{*}{ القوة النسبية } & \multirow{2}{*}{ 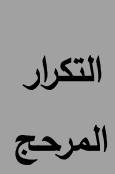 } & ע & 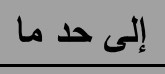 & نعم & \multirow[b]{2}{*}{ 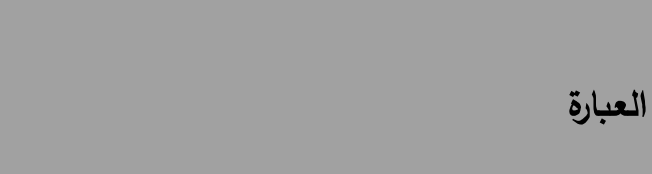 } \\
\hline & & & ك & ك & ك & \\
\hline 2 & 77.69 & 648 & 58 & 70 & 150 & جميع العاملين المقصرين بالمنظمة المراءة المات المسائلة مع \\
\hline 9 & 58.99 & 492 & 143 & 56 & 79 & |قانونية بالمنظفة. \\
\hline 7 & 65.10 & 543 & 130 & 31 & 117 & |العادلة الإدارة إجراءات صارمة تحقيقاً للمسائلة \\
\hline 5 & 70.38 & 587 & 109 & 29 & 140 & تمتلك الإدارة نظام واضح للمسائلة داخل المنظمة \\
\hline 3 & 76.98 & 642 & 73 & 46 & 159 & جيتم ت تنفيذ إجراءات المسائلة بموضوعية على \\
\hline 1 & 79.26 & 661 & 56 & 61 & 161 & |لمتظمة مسائلة المقصرين فى مهام عملهم داخل \\
\hline 8 & 60.31 & 503 & 123 & 85 & 70 & |مسائلة|المقصرين. \\
\hline 6 & 70.02 & 584 & 104 & 42 & 132 & |تحرص الإدارة على جمع المعلومات اللازمة قبل \\
\hline 4 & 74.94 & 625 & 78 & 53 & 147 & |قرارات بعد الجراءات المسائلة لتميع معرفة ماتم التوصل إليه من \\
\hline \begin{tabular}{|c||} 
|القوبة \\
\\
\end{tabular} & المسابي & التكلرارات & & & & \\
\hline 70.41 & 587.22 & 5285 & & & & \\
\hline
\end{tabular}

يتضح من خلال بيانات الجدول (8)أن واقع تطبيق الثفافية الإدارية فى ضوء

المسائلة والمحاسبية بمنظمات الخدمات الاجتماعية جاءت من وجهة نظر العاملين بمديرية 
التضامن الاجتماعى بالفيوم (مجتمع البحث),بقوة نسبية للبعد بلغت(70.41\%),وبمتوسط حسابى مرجح بلغ (587.22),مما ييدل على قوة رؤية المبحوثين.

حيث أشار نسبة (79.26\%) إلى أنه " يتم مسائلة المقصرين فى مهام عملهم داخل

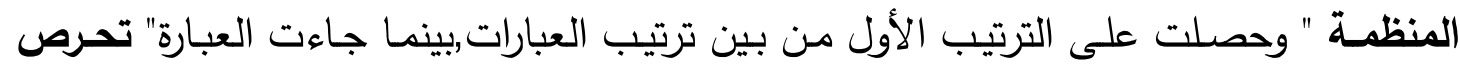

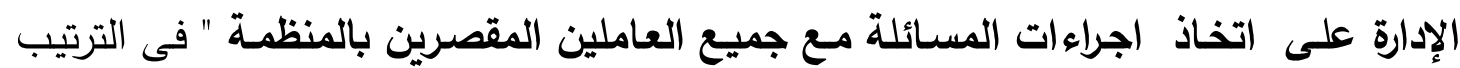
الثانى من بين ترتيب العبارات, بنسبة(77.69\%),فى حين حصلت على الترتيب الثالث من بين ترتيب العبارات العبارة " يتم تنفيذ إجراءات المسائلة بموضوعية على جميع العاملين بالمنظمسة

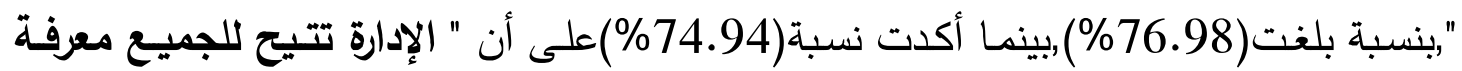

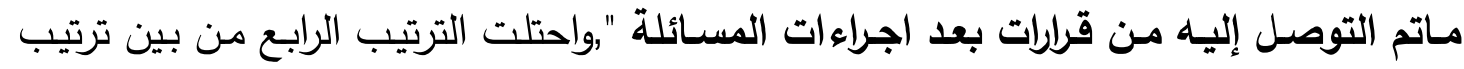

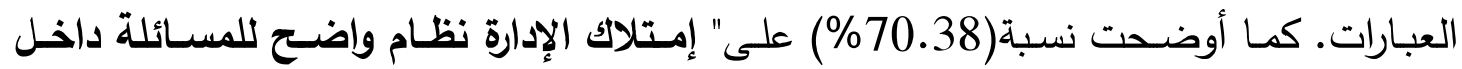
المنظمة ",حيث حصلت على الترتيب الخامس من بين ترتيب العبارات.فى حين أثشارت نسبة (70.02\%) من نفس العينة إلى " حرص الإدارة على جمـع المعلومـات اللازمـة قبل مسـائلة

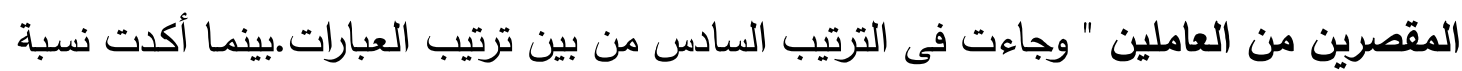

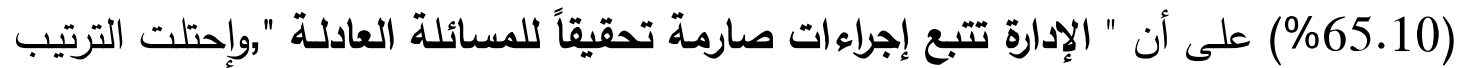

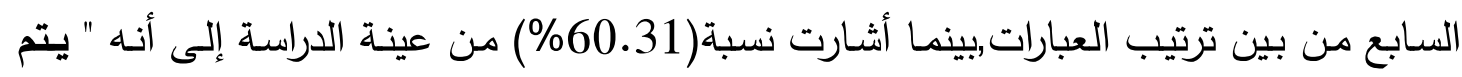

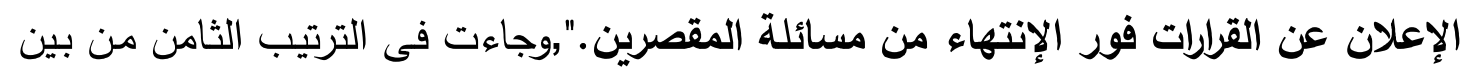

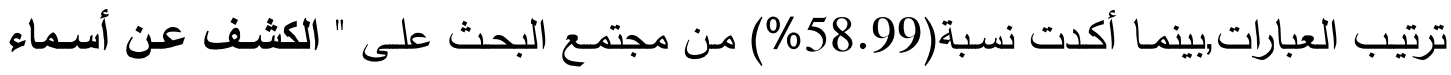
المتورطين بمخالفات قانونية بالمنظمة.",وحصلت على الترتيب التاسع من بين ترتيب العبارات. وبتحليل نتائج الجدول يتضح أن واقع تطبيق الثفافية الإدارية فى ضوء المسائلة

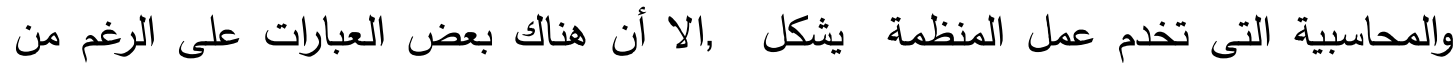

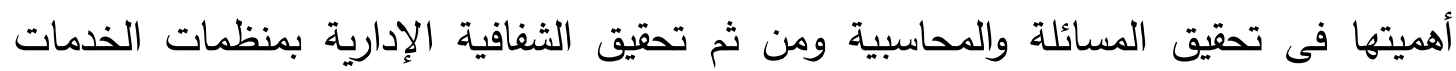

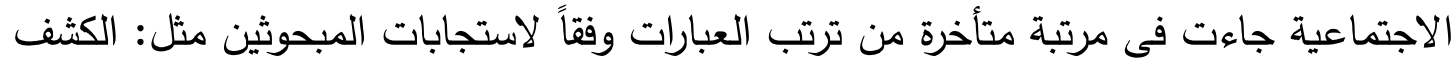
عن أسماء المتورطين بمخالفات قانونية بالمنظمة,الإعلان عن القرارات فور الإنتهاء من مسائلة

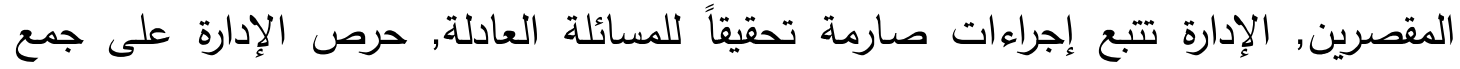
المعلومات اللازمة قبل مسائلة المقصرين من العاملين. 
هـ - واقع تطبيق الثفافية الإدارية فى ضوء مشاركة العاملين فى إتخاذ القرارات الإدارية التى تخدم عمل المنظمة.

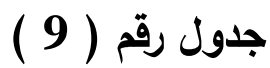

يوضح واقع تطبيق الثفافية الإدارية فى ضوء مشاركة العاملين فى اتخاذ القرارات الإدارية $(278=\dot{0})$

\begin{tabular}{|c|c|c|c|c|c|c|c|}
\hline \multirow[b]{2}{*}{ الترتيب } & \multirow{2}{*}{$\begin{array}{c}\text { النسبية } \\
\text { القوة }\end{array}$} & \multirow{2}{*}{ المرحجر } & لا & \multirow{2}{*}{ إلى حـ ما } & \multirow{2}{*}{ نعم } & \multirow[b]{2}{*}{ | - العبارة } & \multirow[b]{2}{*}{ r } \\
\hline & & & ك & & & & \\
\hline 8 & 64.15 & 535 & 132 & 35 & 111 & بالمبنمة & 1 \\
\hline 11 & 58.39 & 487 & 148 & 51 & 79 & تلغلام عملهم & 2 \\
\hline 9 & 60.31 & 503 & 90 & 61 & 127 & | تأخير & 3 \\
\hline 6 & 69.90 & 583 & 105 & 41 & 132 & 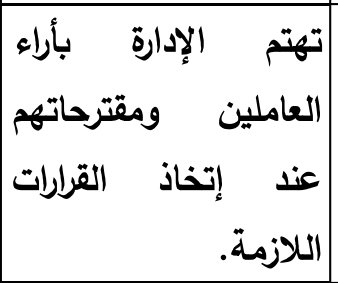 & 4 \\
\hline 1 & 79.98 & 667 & 48 & 71 & 159 & 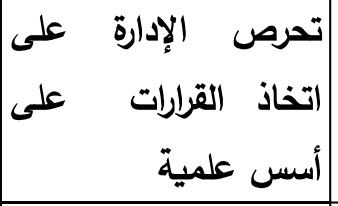 & 5 \\
\hline 4 & 71.82 & 599 & 83 & 69 & 126 & 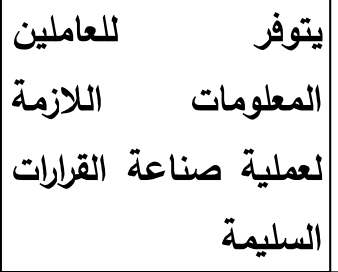 & 6 \\
\hline 5 & 71.58 & 597 & 89 & 59 & 130 & تحرص الإدارة على & 7 \\
\hline
\end{tabular}


مجلة كلية الخدمة الاجتماعية للار اسات و البحوث الاجتماعية ـ جامعة الفيوم

\begin{tabular}{|c|c|c|c|c|c|c|c|c|}
\hline \multirow[b]{2}{*}{ الترتيب } & \multirow{2}{*}{ القوة } & \multirow{2}{*}{ المرحج } & \multicolumn{2}{|l|}{ ل } & \multirow{2}{*}{ إلى حـ ما } & \multirow{2}{*}{ نعم } & \multirow[b]{2}{*}{ | العبارة } & \\
\hline & & & & ك & & & & \\
\hline & & & & & & & 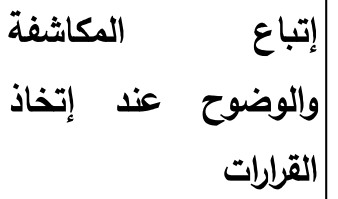 & \\
\hline 3 & 73.74 & 615 & 81 & & 57 & 140 & | التقبل الإدارة الملاحظات & 8 \\
\hline 10 & 70.15 & 502 & 143 & & 46 & 89 & 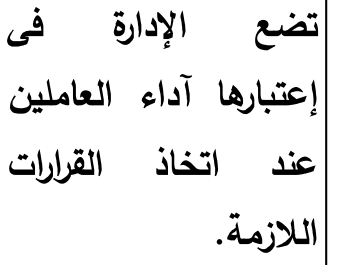 & 9 \\
\hline 2 & 77.34 & 645 & 52 & & 85 & 141 & |تتبنى $\quad$ الإدارة إجراءات & 10 \\
\hline 4 & 71.82 & 599 & 91 & & 53 & 134 & 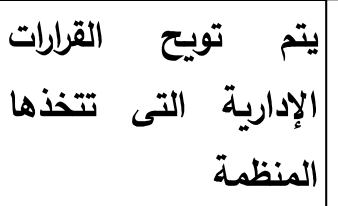 & 11 \\
\hline 7 & 67.75 & 565 & 110 & & 79 & 99 & القيتم مشاركة & 12 \\
\hline 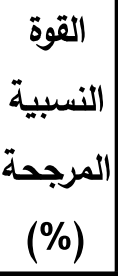 & المسابى المتوسط & التكرارات & ككل & & & & & \\
\hline 68.91 & 574.75 & 6897 & & & & & & \\
\hline
\end{tabular}

يتبين من خلال بيانات الجدول (9)أن واقع تطبيق الشفافية الإدارية فى ضوء مشاركة العاملين فى اتخاذ القرار بمنظمات الخدمات الاجتماعية جاءت من وجهة نظر العاملين بمديرية التضامن الاجتماعى بالفيوم (مجتمع البحث),بقوة نسبية للبعد بلغت(68.91 \%),وبمتوسط حسابى مرجح بلغ (574.75),مما ييدل على قوة رؤية المبحوثين. 356 
حيث أشار نسبة (79.98\%)إلى " حرص الإدارة على اتخاذ القرارات على أسس علمية

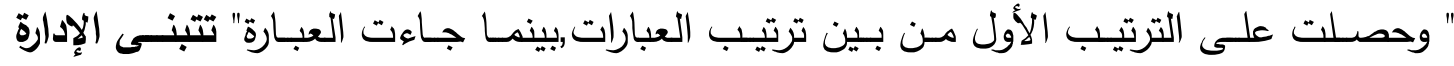

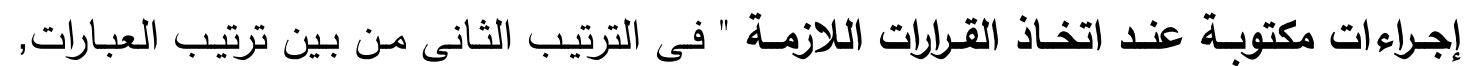
بنسبة(77.34\%),فى حين حصلت على الترتيب الثالث من بين ترتيب العبارات العبارة " تتقبل

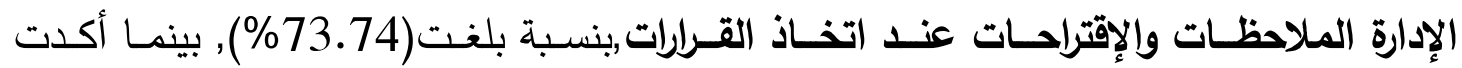
نسبة(71.82\%)على أنه " يتوفر للعاملين المعلومات اللازمة لعملية صناعة القرارات السليمة

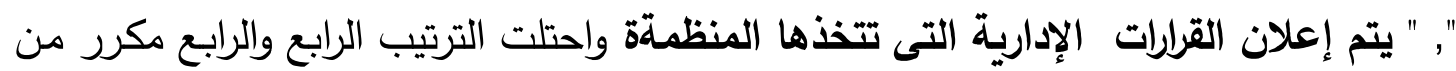

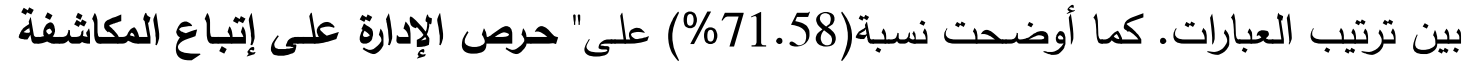

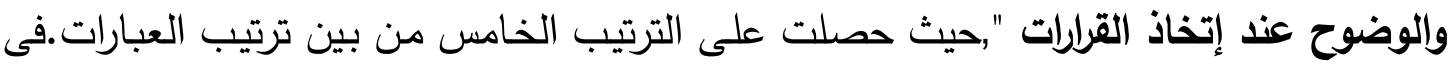

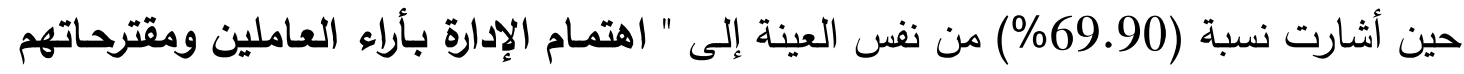

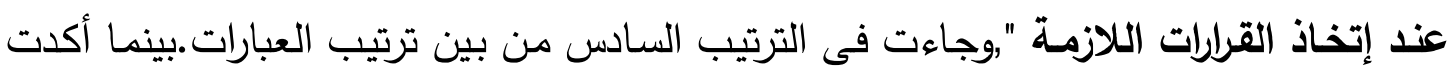

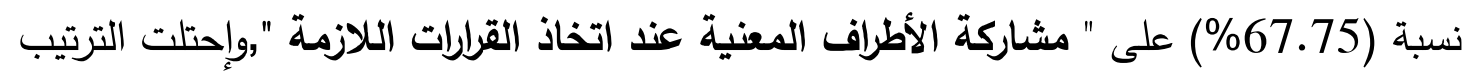

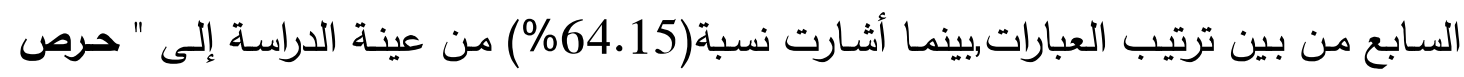

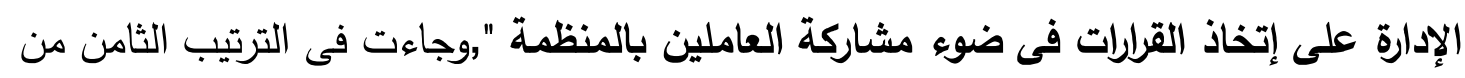

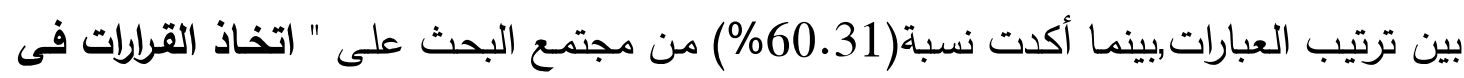

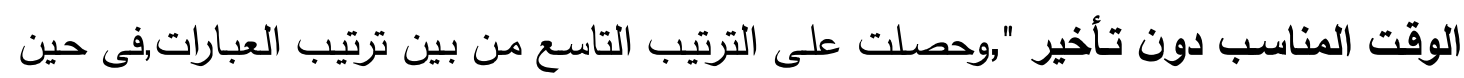

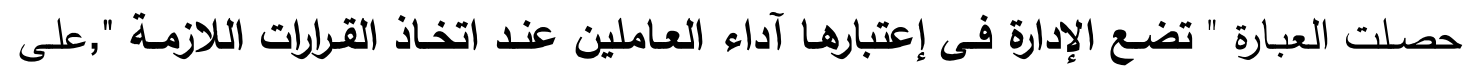

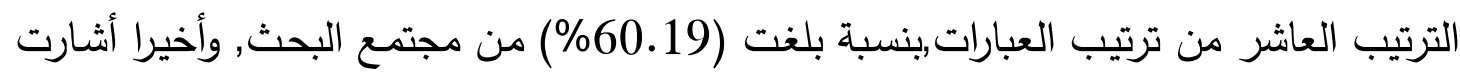
نسبة(58.39\%) من عينـة الدراسة إلى أنه " للعاملين بالمنظمـة الصـلاحيات اللازمـة لاتخـاذ القرارات التى تخدم عملهم ",وجاءت فى الترتيب الحادى عشر من بين ترتيب العبارات. وبتحليل نتائج الجدول يتضح أن واقع تطبيق الثفافية الإدارية فى ضوء مشاركة

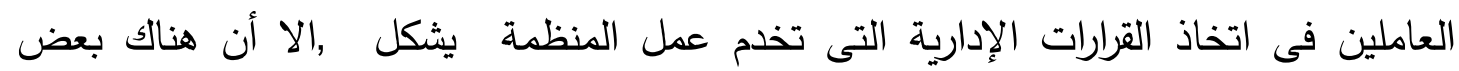
العبارات على الرغم من أهميتها فى تحقيق الثفافية الإدارية بمنظمات الخدمات الإنمات الإنماعية

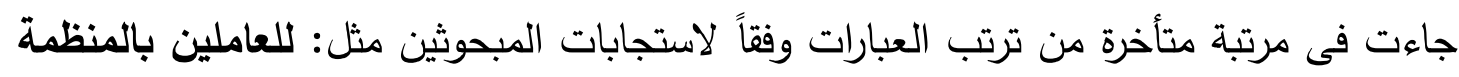
الصلاحيات اللازمة لاتخاذ القرارات التى تخدم عملهم, تضع الإدارة فى إعتبارها آداء العاملين عند اتخاذ القرارات اللازمة, اتخاذ القرارات فى الوقت المناسب دون تأخير التحان 
هـ - واقع تطبيق الثفافية الإدارية فى ضوء اللوائح والإجراءات وأليات العمل, حرص الإدارة على إتخاذ القرارات فى ضوء مشاركة العاملين بالمنظمة.

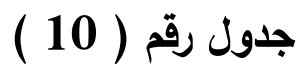

واقع تطبيق الثفافية الإدارية فى ضوء اللوائح والإجراءات وأليات العمل من وجهة نظر العاملين (278) بمنظمات الخدمات الاجتماعية(مجتمع البحث)

\begin{tabular}{|c|c|c|c|c|c|c|c|}
\hline & القوة & & $y$ & إلى حـ ما & نعم & & \\
\hline الترتيب & $\begin{array}{l}\text { النسبية } \\
\text { (\%) }\end{array}$ & المرحج & ك & ك & ك & |العبارة & \\
\hline 10 & 65.35 & 545 & 123 & 43 & 112 & | وإجراء ت توضيح أليات العمل & 1 \\
\hline 3 & 78.18 & 652 & 65 & 52 & 161 & | والقواعد & 2 \\
\hline 8 & 67.62 & 564 & 119 & 32 & 127 & | الموقف & 3 \\
\hline 4 & 71.22 & 594 & 99 & 42 & 137 & | تعزيزا للعمل الجماعى إجراءات العمل & 4 \\
\hline 2 & 81.29 & 687 & 31 & 94 & 153 & 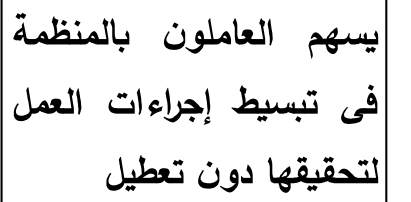 & 5 \\
\hline 9 & 66.79 & 557 & 105 & 67 & 106 & 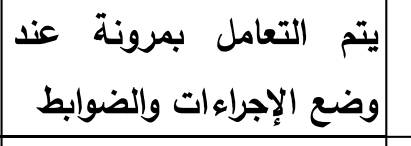 & 6 \\
\hline 12 & 61.99 & 517 & 117 & 83 & 78 & |قبل إقرارها & 7 \\
\hline 5 & 70.14 & 585 & 104 & 41 & 133 & 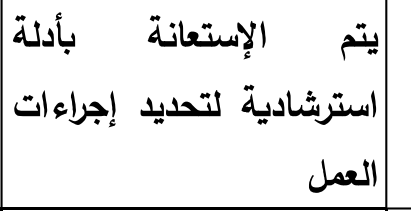 & 8 \\
\hline 1 & 88.60 & 739 & 28 & 63 & 195 & |بالقوانين $\quad$ تبصير $\quad$ والتشريعات & 9 \\
\hline
\end{tabular}




\begin{tabular}{|c|c|c|c|c|c|c|c|}
\hline \multirow[b]{2}{*}{ الترتيب } & \multirow{2}{*}{ النسبية } & \multirow{2}{*}{ المرحج } & ע & إلى حل ما & ن مم & \multirow[b]{2}{*}{ | العبارة } & \multirow[b]{2}{*}{$\imath^{2}$} \\
\hline & & & كs & كs & كs & & \\
\hline & & & & & & |المنظمة للعمل. & \\
\hline 7 & 67.99 & 567 & 98 & 71 & 109 & | تحرص الإدارة على مراجعة & 10 \\
\hline 6 & 68.10 & 568 & 115 & 36 & 127 & | تطبق اللوائح والقوانين على & 11 \\
\hline 11 & 63.91 & 527 & 118 & 71 & 89 & 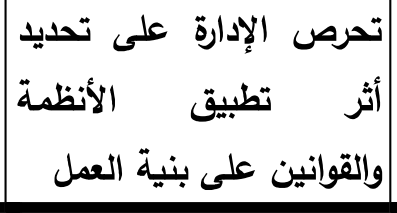 & 12 \\
\hline القوة النسبية & المتوسط المسابي & التكرارات & ككل & & & & \\
\hline 70.96 & 591.83 & 7102 & & & & & \\
\hline
\end{tabular}

يتضح من خلال بيانات الجدول (10)أن واقع تطبيق الثفافية الإدارية فى ضوء اللوائح والإجراءات وأليات العمل بمنظمات الخدمات الاجتماعية جاءت من وجهة نظر العاملين بمديرية

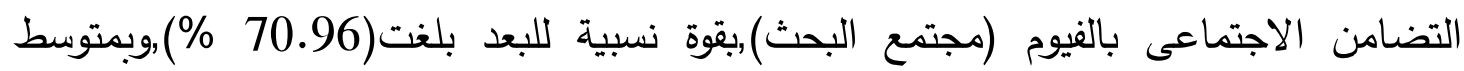
حسابى مرجح بلغ (591.83),مما ييدل على قوة رؤية المبحوثين.

حيث أشـار نسبة (88.60\%)إلسى أنسه" يـتم تبصسير العـاملين بـالقوانين والتشـريعات

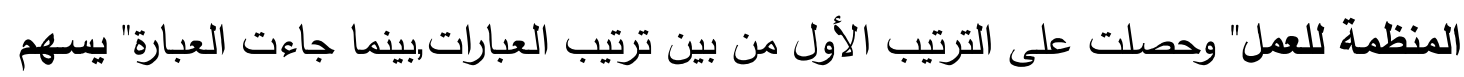
العاملون بالمنظمة فى تبسيط إجراءات العمل لتحقيقها دون تعطيل" فى الترتيب الثانى من بين لتين

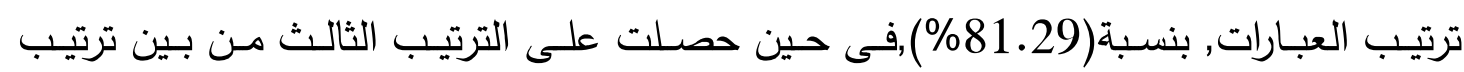

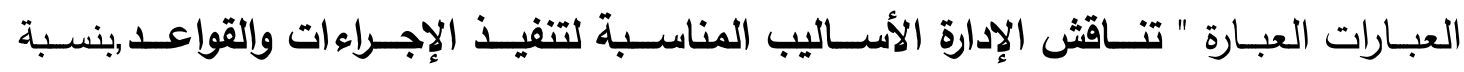
بلغت(78.18\%), بينما أكدت نسبة(71.22\%)على "مشـاركة العاملون بالمنظمـة فـى تحديد

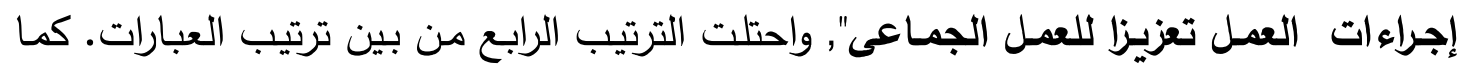

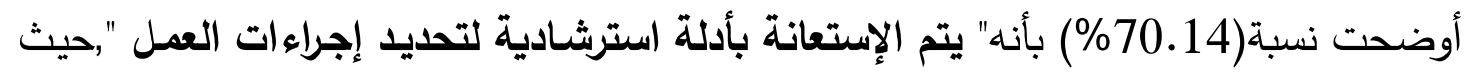
حصلت على الترتيب الخامس من بين ترتيب العبارات.فى حين أشارت نسبة (68.10\%) من الأنعانه بادلة 
نفس العينة إلى " تطبيق اللوائح والقوانين على الجميع دون استثناء ",وجاءت فى الترتيب

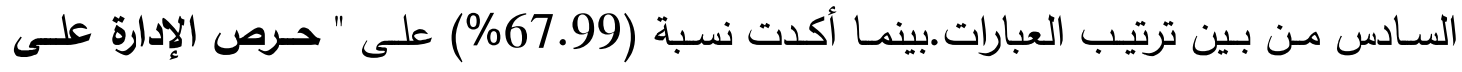

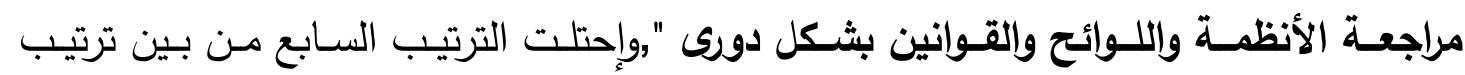

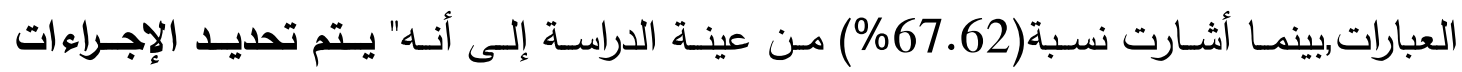

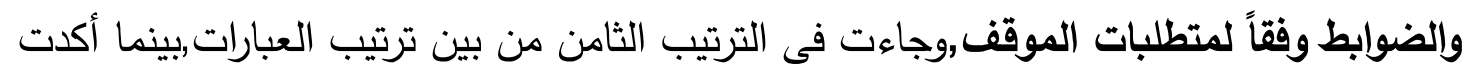

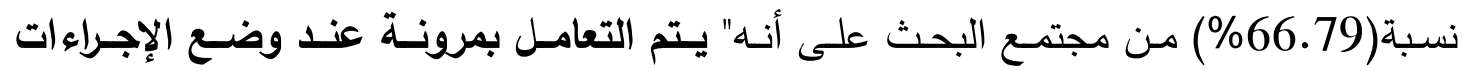
والضوابط ",وحصلت على الترتيب التاسع من بين ترتيب العبارات,فى حين حصلت العبارة " يتم

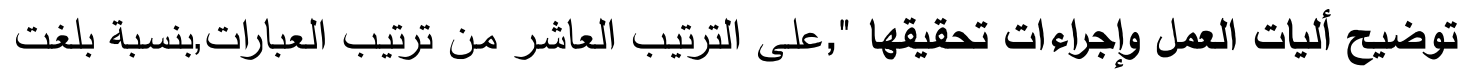

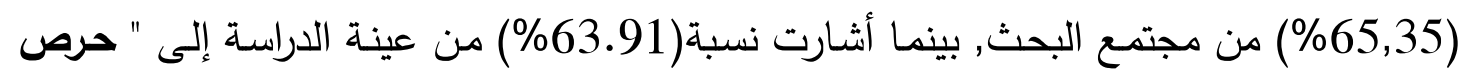

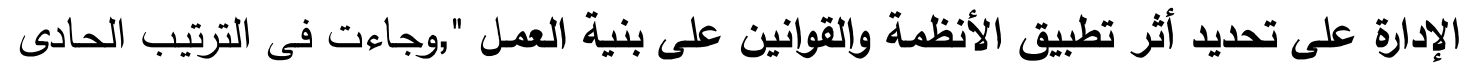

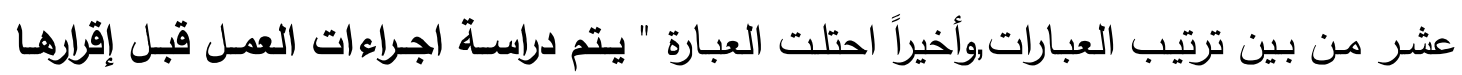

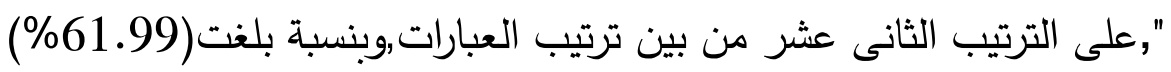
وبتحليل نتائج الجدول يتضح أن واقع تطبيق الثنافية الإدارية فى ضوه اللوائح

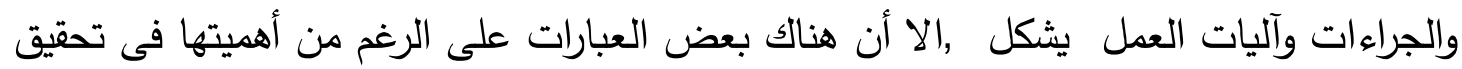

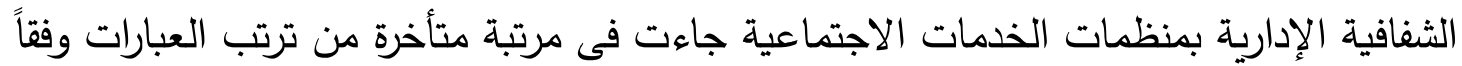
لاستجابات المبحوثين مثل: حرص الإدارة على تحديد أثر تطبيق الأنظمة والقوانين على بنية العمل,حرص الإدارة على تحديد أثر تطبيق الأنظمة والقوانين على بنية العمل, يتم التعامل بمرونة عند وضع الإجراءات والضوابط. 
مجلة كلية الخدمة الاجتماعية للدر اسات و البحوث الاجتماعية - جامعة الفيوم

ثانياً:. معوقات تطبيق الثفافية الإدارية بمنظمات الخدمات الاجتماعية:--

جدول رقم (11)

يوضح معوقات تطبيق الثفافية الإدارية من وجهة نظر العاملين بمنظمات الخدمات الاجتماعية $(278=\dot{0})$

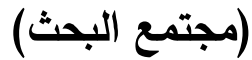

\begin{tabular}{|c|c|c|c|c|c|c|c|}
\hline \multirow[b]{2}{*}{ الترتيب } & \multirow{2}{*}{ |القوة النسبية } & \multirow{2}{*}{ 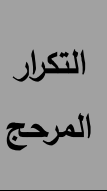 } & ע & إلى حد ما & نعم & \multirow[b]{2}{*}{ العبارة } & \multirow[b]{2}{*}{ ? } \\
\hline & & & $\begin{array}{l}5 \\
\%\end{array}$ & ك5 & ك5 & & \\
\hline 8 & 71.22 & 594 & 79 & 82 & 117 & ضعف البناء التظظيمى والمؤسسى. & 1 \\
\hline 14 & 65.35 & 545 & 99 & 91 & 88 & سنشطترة بعض لمصالح شخصية المنظمة على & 2 \\
\hline 5 & 72.30 & 603 & 59 & 113 & 106 & الإإنفراد بإصدار القرارات دون إستشارة & 3 \\
\hline 2 & 80.22 & 669 & 47 & 71 & 160 & العاملين المقصرين في تطبيق ألجزاء ات مهامهم. & 4 \\
\hline 1 & 82.13 & 685 & 30 & 89 & 159 & غياب الآليات المؤسسية التى تحكم & 5 \\
\hline 11 & 69.18 & 577 & 74 & 79 & 115 & ضعفف ممارسة الايمقراطية فى اتخاذ & 6 \\
\hline 16 & 59.59 & 497 & 146 & 45 & 87 & 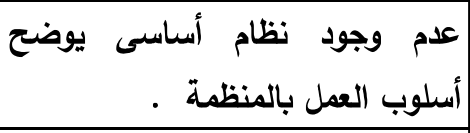 & 7 \\
\hline 7 & 71.34 & 595 & 88 & 69 & 122 & مركزية إتخاذ القرار بالمنظمة & 8 \\
\hline 4 & 72.90 & 608 & 47 & 132 & 99 & 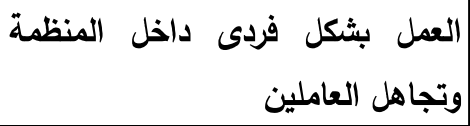 & 9 \\
\hline 15 & 63.55 & 503 & 124 & 83 & 71 & بالمنظمة العدالة فى معاملة العاملين & 10 \\
\hline 18 & 57.55 & 480 & 129 & 96 & 53 & الإدارة. غياب الثفافية المعلوماتية من قبل & 11 \\
\hline 19 & 56.47 & 471 & 155 & 53 & 70 & حقيقية بالمنظمة. & 12 \\
\hline 10 & 69.42 & 579 & 86 & 83 & 109 & العاملين. غياب عنر المسائلة عند تقصير & 13 \\
\hline
\end{tabular}


مجلة كلية الخدمة الاجتماعية للدر اسات و البحوث الاجتماعية ـ جامعة الفيوم

\begin{tabular}{|c|c|c|c|c|c|c|c|}
\hline \multirow[b]{2}{*}{ الترتيب } & \multirow{2}{*}{ | القوة النسبية } & \multirow{2}{*}{ المرحج } & $y$ & إلى حد ما & نعم & \multirow[b]{2}{*}{ | العبارة } & \\
\hline & & & \% & كs & كs & & \\
\hline 9 & 70.74 & 590 & 90 & 64 & 124 & توالضدد الإدارة عند وضع الإجراءات & 14 \\
\hline 17 & 58.39 & 487 & 128 & 91 & 59 & 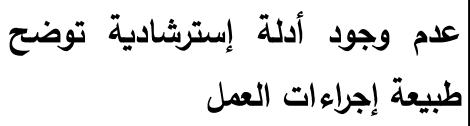 & 15 \\
\hline 13 & 65.59 & 547 & 108 & 71 & 99 & تطبيق الإجراءات واللوائح والقوانين & 16 \\
\hline 3 & 74.64 & 621 & 76 & 61 & 141 & 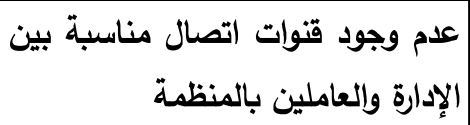 & 17 \\
\hline 6 & 72.18 & 602 & 105 & 22 & 151 & المسائلة داخل المنظمة و واضحد لعملية & 18 \\
\hline 12 & 65.95 & 550 & 125 & 34 & 119 & الإدارة بعد مسائلة الخفاء القرارات التى تتذذها & 19 \\
\hline 20 & 55.99 & 467 & 143 & 81 & 54 & 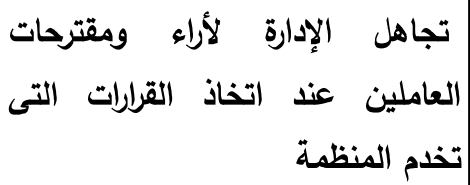 & 20 \\
\hline |القوة النسبية & المسابي & $\begin{array}{l}\text { التكرارات } \\
\text { المرجمةع }\end{array}$ & ككل & & & & \\
\hline$\% 67.5$ & 563.5 & 11270 & & & & & \\
\hline
\end{tabular}

بإستقراء بيانات الجدول (11) والذي يوضح معوقات تطبيق الثفافية الإدارية من وجهة نظر الترائ العاملين بمنظمات الخدمات الاجتماعية (مجتمع البحث) حيث يتبين أنها تتوزع توزيعاً إحصائياً وفق مجموع التكرارات المرجحة لهذه الإستجابات والذي بلغ (5630) (11270) وبمتوسط حسابي عام مرجح (563.5) وقوة نسبية (67.5\%) ،وجاءت إستجابات المبحوثين من العاملين بمنظمات

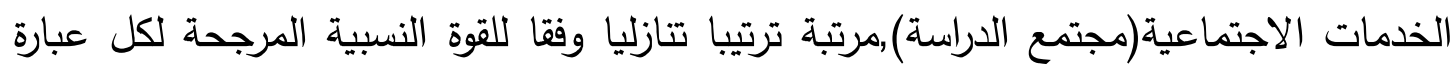

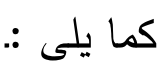

1. جاءت العبارة " غياب الآليات المؤسسية التى تحكم طبيعة العمل بالمنظمة " فى الترتيب الأول, بقوة نسبية بلغت (82.13\%) 
2. وفي الترتيب الثاني جاءت العبارة" التساهل في تطبيق الجزاءات على العاملين المقصرين في أداء مهامهم." بقوة نسبية (80.22\%)

3. وحصلت على الترتيب الثالث العبارة " عدم وجود قنوات اتصال مناسبة بين الإدارة والعاملين بالمنظمة " بقوة نسبية (74.46\%).

4. في حين حصلت على الترتيب الرابع العبارة " العمل بثكل فردى داخل المنظمة وتجاهل العاملين "بقوة نسبية (72.90\%).

5. وجاء فى الترتيب الخامس العبارة " الإنفراد بإصدار القرارات دون إستشارة العاملين " بقوة

$$
\text { نسبية (72.30\%). }
$$

6. في حين حصلت على الترتيب السادس والسادس مكرر العبارات " غياب نظام واضح ومحدد لعملية المسائلة داخل المنظمة "، بقوة نسبية (72.18\%).

7. بينما جاءت فى الترتيب السابع العبارة " مركزية إتخاذ القرار بالمنظمة "بقوة نسبية .$(\% 71.34)$

8. وحصلت على الترتيب الثامن العبارة" ضعف البناء التظظيى والمؤسسى " بقوة نسبية .$(\% 71.22)$

9. بينما إحتلت الترتيب التاسع العبارة " تثدد الإدارة عند وضع الإجراءات والضوابط المنظمة للعمل " بقوة نسبية (70.74\%). 10. "غياب عنصر المسائلة عند تقصير العاملين " بقوة نسبية (69.42\%). 11. في حين جاء فى الترتيب الحادي عشر العبارة " ضعف ممارسة الايمقراطية فى اتخاذ القرارات داخل المنظمة. " بقوة نسبية (69.18\%). 
12. وحصلت على الترتيب الثاني عشر العبارة " تعمد إخفاء القرارات التى تتخذها الإدارة بعد مسائلة المقصرين " بقوة نسبية (65.95\%). 13. واحتلت الترتيب الثالث عشر العبارة " تطبيق الإجراءات واللوائح والقوانين على فئة دون غيرها من العاملين " بقوة نسبية (55.59\%).

14. وحصلت على الترتيب الرابع عشر العبارة " سيطرة بعض قيادات المنظمة على أنشطتها لمصالح شخصية " بقوة نسبية (65.35 \%).

15. في حين جاء فى الترتيب الخامس عشر العبارة " غياب العدالة فى معاملة العاملين

$$
\text { بالمنظمة. " بقوة نسبية (63.55\%). }
$$

16. وحصلت على الترتيب السادس عشر العبارة " عدم وجود نظام أساسى يوضح أسلوب العمل بالمنظمة " بقوة نسبية (59.59\%).

17. وجاء فى الترتيب السابع عشر العبارة " عدم وجود أدلة إسترشادية توضح طبيعة إجراءات العمل " بقوة نسبية (58.39\%).

18. وحصلت على الترتيب الثامن عشر العبارة " غياب الثفافية المعلوماتية من قبل الإدارة " بقوة نسبية (57.55 \% ).

19. في حين جاء فى الترتيب التاسع عشر العبارة " عدم توافر قواعد بيانات ومعلومات حقيقية بالمنظمة " بقوة نسبية (56.47\%).

20. وأخيراً حصلت على الترتيب العشرون العبارة " تجاهل الإدارة لأراء ومقترحات العاملين عند اتخاذ القرارات التى تخدم المنظمة " بقوة نسبية (55.99\%). ولقد جاءت مجموعة من المعوقات التى تحد من تطبيق الثفافية الإدارية في مراتب متأخرة على الرغم من تأثيرها فى تحقيق الشفافية الإداريتبمنظمات الخدمات الاجتماعية والمتمثلة فى: 
1- تجاهل الإدارة لأراء ومقترحات العاملين عند اتخاذ القرارات التى تخدم المنظمة 2- عدم توافر قواعد بيانات ومعلومات حقيقية بالمنظمة.

3- غياب الثفافية المعلوماتية من قبل الإدارة. 4- عدم وجود أدلة إسترشادية توضح طبيعة إجراءات العمل. 5- عدم وجود نظام أساسى يوضح أسلوب العمل بالمنظمة. 6- سيطرة بعض قيادات المنظمة على أنشطتها لمصالح شخصية 7- تطبيق الإجراءات واللوائح والقوانين على فئة دون غيرها من العاملين ويتضح مماسبق أن أكثر المعوقات التي تحد من تطبيق الثفافية الإدارية بمنظمات الخدمات الاجتماعية من وجهة نظر العاملين بمديرية التضامن الاجتماعى بالفيوم,تمثلت في: غياب الآليات المؤسسية التى تحكم طبيعة العمل بالمنظمة,التساهل في تطبيق الجزاءات على العاملين المقصرين في أداء مهامهم,عدم وجود قنوات اتصال مناسبة بين الإدارة والعاملين بالمنظمة,العمل بشكل فردى داخل المنظمة وتجاهل العاملين,غياب نظام واضح ومحدد لعملية المسائلة داخل المنظمة. ثالثاً:. مقترحات تفعيل تطبيق الثفافية بمنظمات الخدمات الاجتماعية الأهلية:. جدول رقم (12) - (12) - (1)

مقترحات تفعيل تطبيق الشفافية بمنظمات الخدمات الاجتماعية من وجهة نظر العاملين

\begin{tabular}{|c|c|c|c|c|}
\hline \multicolumn{2}{|c|}{$(278=0)$} & \multicolumn{3}{|c|}{ (مجتمع البحث) } \\
\hline الترتي & النسبة\%\% & التكرار & الاجتماعية مقرحات تفعيل تطبيق الثفافية بمنظمات الخدمات & 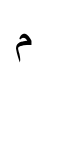 \\
\hline 10 & 74.46 & 207 & العمل على إيجاد آليات مؤسسية فاعلة تحكم العمل بالمنظمة & 1 \\
\hline 12 & 69.78 & 194 & اتباع إسلوب اللامركزي الإدارية داخل المنظمة & 2 \\
\hline 1 & 100 & 278 & الإهتمام بالمصلحة العامة على حساب المصلحة الشخصية. & 3 \\
\hline 6 & 88.85 & 247 & توفير مناخ إدارى ملائم للعمل بكفاءة . & 4 \\
\hline 1 م & 100 & 278 & الإهتمام بإشرالك العاملين في إتخاذ القرارات التى تخدم & 5 \\
\hline
\end{tabular}


مجلة كلية الخدمة الاجتماعية للار اسات و البحوث الاجتماعية - جامعة الفيوم

\begin{tabular}{|c|c|c|c|c|}
\hline 1 & 100 & 278 & تحقيق العدالة بين جميع العاملين بالمنظمة & 6 \\
\hline 2 & 97.84 & 272 & تحقيق المسائلة الفاعلة عند حدوث تقصيرجسيم من بعض & 7 \\
\hline 3 & 93.16 & 259 & أيجاد نظام واضح وفعال للمحاسبة داخل المنظمة. & 8 \\
\hline 7 & 85.97 & 239 & توفير قواعد بيانات ومعلومات حديثة بالمنظمة & 9 \\
\hline 1 & 100 & 278 & تطبيق الإجراءات واللوائح والقوانين على الجميع دون إستثناء. & 10 \\
\hline 4 & 91.37 & 254 & العدل على إيجاد قنوات إتصال فاعلة توفر المعلومات من & 11 \\
\hline 9 & 75.89 & 211 & التواصل المستصر مع العاملين فى وضع خطط تطوير & 12 \\
\hline 11 & 71.94 & 200 & تحقيق الشفافية المعلوماتية بالمنظمة. & 13 \\
\hline 5 & 70.29 & 251 & العمل الجماعى مع إحترام أراء العاملين بالمنظمة & 14 \\
\hline 13 & 67.99 & 189 & إعلان نتائج تقييم أداء العاملين بالمنظمة & 15 \\
\hline 8 & 78.68 & 219 & التوفير كافة المعلومات والبيانات اللازمة لصناعة القرارات & 16 \\
\hline م7 & 85.97 & 239 & عدم التساهل في تطبيق الجزاءات مع العاملين المقصرين & 17 \\
\hline
\end{tabular}

بإستقراء بيانات الجدول( 12 ) يتبين أن مقترحات تفعيل تطبيق الشفافية الإدارية بمنظمات الخدمات الاجتماعية من وجهة نظر العاملين(مجتمع البحث) جاءت مرتبة ترتيباً تنازلياً كالتالى : 1- اتباع إسلوب اللامركزي الإدارية داخل المنظمة,الإهتمام بإشراك العاملين في إتخاذ القرارات التى تخدم المنظمة, تحقيق العدالة بين جميع العاملين بالمنظمة, تطبيق الإجراءات واللوائح والقوانين على الجميع دون إستثناء بنسبة بلغت(100\%). 
2-تحقيق المسائلة الفاعلة عن حدوث تقصيرجسيم من بعض العاملين,بنسبة بلغت

3- أيجاد نظام واضح وفعال للمحاسبة داخل المنظمة, بنسبة بلغت(93,16\%).

4- العمل على إيجاد قنوات إتصال فاعلة توفر المعلومات من الإدارة للعاملين,بنسبة بلغت (\%1,37).

5- العمل الجماعى مع إحترام أراء العاملين بالمنظمة, بنسبة بلغت(90,29\%).

6- توفير مناخ إدارى ملائم للعمل بكفاءة, بنسبة بلغت(88,85\%).

7- توفير قواعد بيانات ومعلومات حديثة بالمنظمة, عدم التساهل في تطبيق الجزاءات مع العاملين المقصرين بنسبة بلغت (85,97\%).

8- توفير كافة المعلومات والبيانات اللازمة لصناعة القرارات التى تخدم المنظمة, بنسبة بلغت (\%78,68).

9- التواصل المستمر مع العاملين فى وضع خطط تطوير المنظمة, بنسبة بلغت(75,89\%). 10- العمل على إيجاد آليات مؤسسية فاعلة تحكم العمل بالمنظمة, بنسبة بلغت(74,46\%). 11- تحقيق الثفافية المعلوماتية بالمنظمة,بنسبة بلغت (71,94\%). 12- اتباع إسلوب اللامركزي الإدارية داخل المنظمة,بنسبة بلغت(69,78\%). 13-إعلان نتائج تقييم أداء العاملين بالمنظمة,بنسبة بلغت(67,99\%).

\section{سابعاً: النتائج العامة للدراسة}

1- النتائج المرتبط بالاجابة على التساؤل الرئيسى الأول للدراسة ومؤداه: ما واقع تطبيق الثفافية الإدارية بمنظمات الخدمات الاجتماعية,حيث كثفت الدراسة عن مجموعة من النتائج الجديرة بالإعتبار والمتمثلة فيما يلى:

ـ نتائج مرتبطة بواقع تطبيق الثفافية الإدارية فى ضوء نظم المعلومات كما حدها العاملون بمديرية التضامن(مجتمع البحث)والتى تمثلت فى:. توافر المعلومات للعاملين فى الوقت المناسب لتمكينهم من أداء مهامهم,مع إتاحة المعلومات المالية للعاملين بالمنظمة, تحرى المصداقية خلال طرح المعلومات المرتبطة بمهام العمل.بجانب حرص الإدارةعلى 
توفير وسائل تكنولوجيا المعلومات اللازمة لمهام العمل.ضعف حرص الإدارة على تزويد

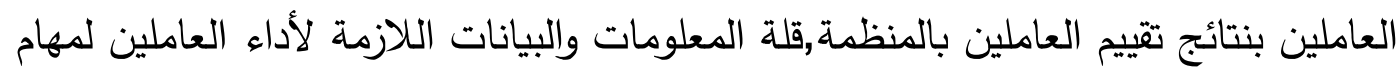

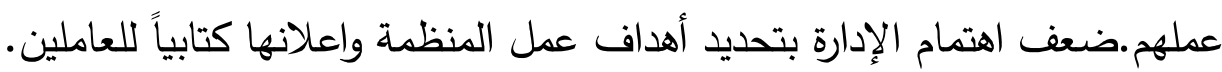

. نتائج مرتبطة بواقع تطبيق الثفافية الإدارية فى ضوء نظام الاتصال القائم كما حددها

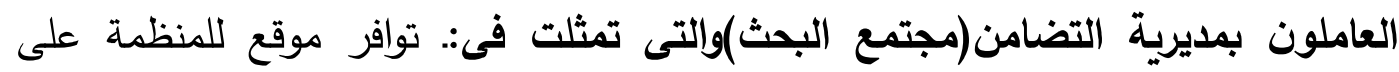
شبكة الانترنت لعرض انجازاتها.توفر المنظمة وسائل اتصال متعددة لانجاز مهام العمل

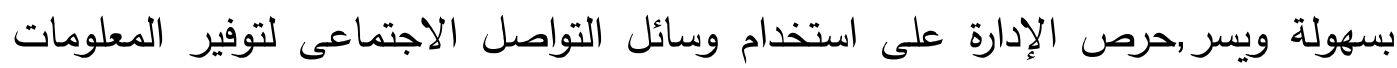

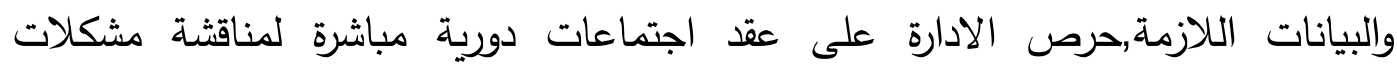

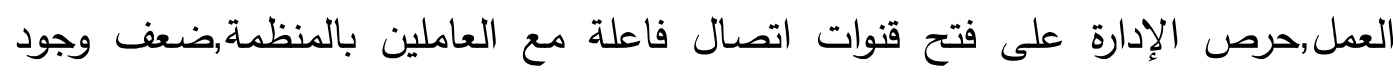
قنوات اتصال لتلقى شكاوى العاملين بالمنظمة,قلةقاستخدام العاملون لوسائل الاتصال المباشرة مع الادارة دون قيود,ضعف حرص الإدارة على تطوير قنوات الاتصال مع العاملين

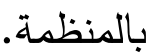

. نتائج مرتبطة بواقع تطبيق الثفافية الإدارية فى ضوء نظام المسائلة والمحاسبيةً كما

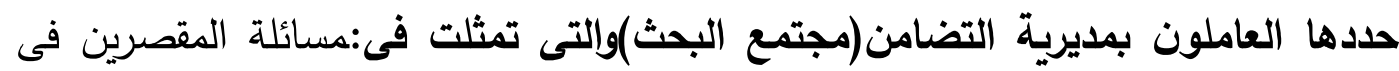
مهام عملهم داخل المنظمة, حرص الإدارة على اتخاذ اجراءات المسائلة مع جميع العاملين المقصرين بالمنظمة, تتفيذ إجراءات المسائلة بموضوعية على جميع العاملين بالمنظمة, الإدارة عدم اتاحة المعلومات لمعرفة ماتم التوصل إليه من قرارات بعد اجراءات المسائلة,عدم الداءع

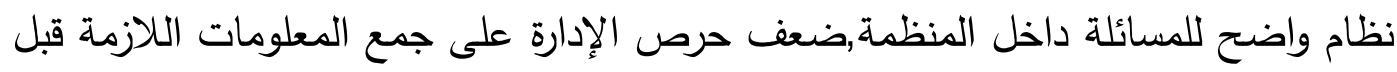

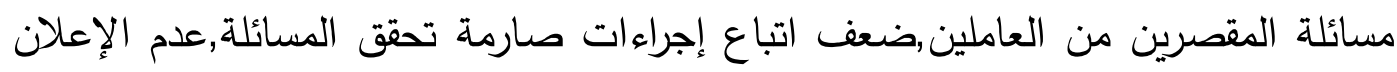
عن القرارات فور الإنتهاء من مسائلة المقصرين,ضعف الهتمام الادارة بالكثف عن أسماء أسماء المتورطين بمخالفات قانونية بالمنظمة,

• نتائج مرتبطة بواقع تطبيق الثفافية الإدارية فى ضوء مشاركة العاملين فى اتخاذ

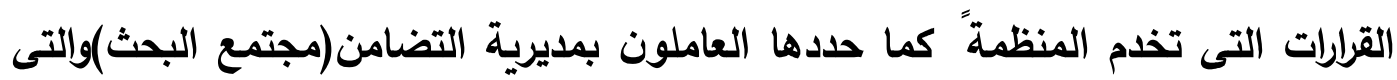

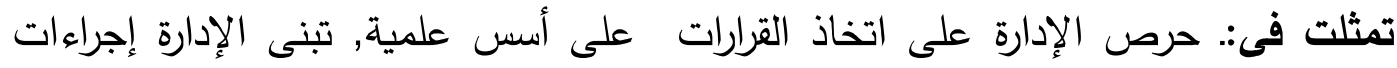

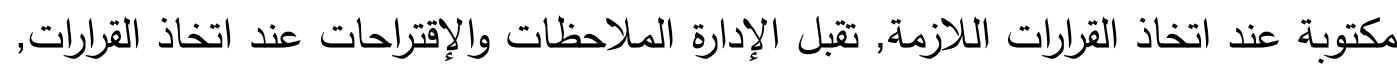
توفر المعلومات اللازمة لعملية صناعة القرارات السليمة,قلة اهتمام الادارة بإعلان القرارات 
الإدارية التى تتخذهاضصف حرص الإدارة على إتباع المكاشفة والوضوح عند إتخاذ

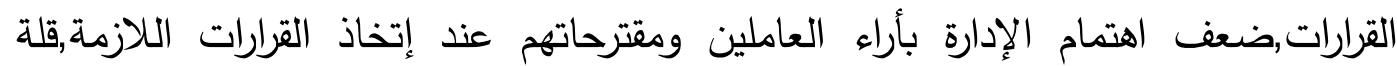

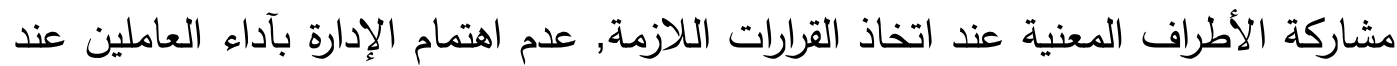

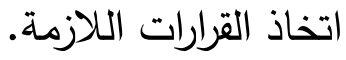

ـ نتائج مرتبطة بواقع تطبيق الثفافية الإدارية فى ضوء لوائح وإجراءات وأليات العمل كما حددها العاملون بمديرية التضامن(مجتمع البحث)والتى تمثلت فى:تبصير العاملين بالقوانين والتشريعات المنظمة للعمل,مساندة العاملون بالمنظمة فى تبسيط إجراءات العمل لتحقيقها

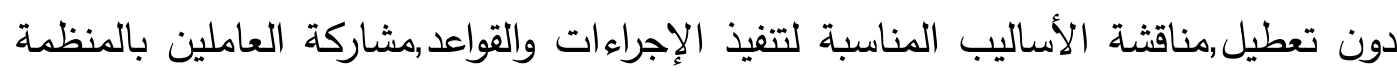
فى تحديد إجراءات العمل تعزيزا للعمل الجماعى,ضعف الإستعانة بأدلة استرشادية لتحديد

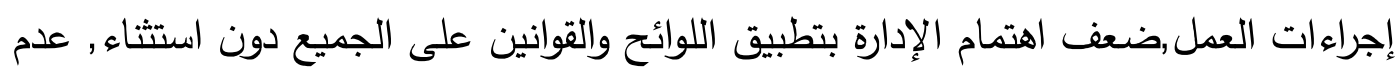

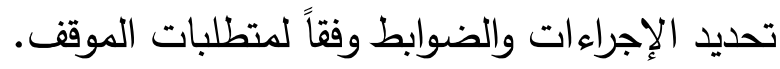

\section{2- النتائج المرتبط بالاجابة على التساؤل الرئيسى الثانى للدراسة ومؤداه:}

\section{ما المعوقات التى تحد من تطبيق الثفافية الإدارية بمنظمات الخدمات الاجتماعية؟حيث} أظهرت الدراسة ومن وجهة نظر المبحوثين مجموعة من المعوقات المتمثلة فيما يلى:.

أ- - غياب الآليات المؤسسية التى تحكم طبيعة العمل بالمنظمة.

2- التساهل في تطبيق الجزاءات على العاملين المقصرين في أداء مهامهم. 3- العمل بشكل فردى داخل المنظمة وتجاهل العاملين. 4- الإنغراد بإصدار القرارات دون إستشارة العاملين

5- غياب نظام واضح ومحدد لعملية المسائلة داخل المنظمة. 6- تشدد الإدارة عند وضع الإجراءات والضوابط المنظمة للعمل. 7- غياب عنصر المسائلة عند تقصير العاملين. 8- ضعف ممارسة الديمقراطية فى اتخاذ القرارات داخل المنظمة. 
9- تعدد إخفاء القرارات التى تتخذها الإدارة بعد مسائلة المقصرين. 10- تطبيق الإجراءات واللوائح والقوانين على فئة دون غيرها من العاملين. 11- سيطرة بعض قيادات المنظمة على أنشطتها لمصالح شخصية. 12- عدم وجود نظام أساسى يوضح أسلوب العمل بالمنظمة. 13- عدم توافر قواعد بيانات ومعلومات حقيقية بالمنظمة . 14- تجاهل الإدارة لأراء ومقترحات العاملين عند اتخاذ القرارات التى تخدم المنظمة. ثامناً: المؤشرات التخطيطية لتفعيل تطبيق الثفافية الإدارية من خلال ما توصلت إليه الدراسة الراهنة من نتائج,فى ضوء إستجابات المبحوثين من العاملين بمنظمات الخدمات الاجتماعية,والاجابة على التساؤلات الأساسية والفرعية للدراسة,يمكن وصع مجموعة من المؤشرات التخطيطية لتفعيل تطبيق الثفافية الإدارية بمنظمات الخدمات

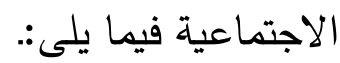

1- مؤشرات تخطيطية لتفعيل تطبيق الشفافية الادارية من خلال تفعيل نظم المعلومات القائمة بالمنظمة,حيث يتم تحقيق ذلك من خلال:. • توفير المعلومات للعاملين فى الوقت المناسب لتمكينهم من أداء مهامهح. • قيام الإدارة بتوفير المعلومات المالية لجميع العاملين بالمنظمة. ـ اهتمام الإدارة بالمصداقية خلال طرح المعلومات المرتبطة بمهام العمل. . توفير وسائل تكنولوجيا المعلومات اللازمة لمهام العمل. ـ تحرى الدقة والمصداقية فى توفيرالمعلوماتوالبيانات التى يحتاجها العاملون بالمنظمة.. . تزويد العاملين بالمنظمة بنتائج تقييم إدائهم. . توفير المعلومات الخاصة بمهام العمل داخل المنظمة. . تحديد أهداف عمل المنظمة وإعلانها كتابياً للعاملين 
2- مؤشرات تخطيطية لتفعيل تطبيق الثفافية الادارية من خلال تفعيل نظام الاتصال القائم بالمنظمة,حيث يتم تحقيق ذلك من خلال:. . توفير موقع على شبكة الانترنت لعرض انجازات المنظمة. . توفير وسائل اتصال متعددة لانجازمهام العمل بسهولة ويسر. ـ استخدام وسائل التواصل الاجتماعى لتوفير المعلومات والبيانات اللازمة. ـ التزام الإدارة بعقد اجتماعات دورية مع العاملين مباشرة لمناقثة مشكلات العمل. ـ فتح قنوات اتصال فاعلة مع العاملين بالمنظمة. . مراعاة فتح قنوات اتصال لتلقى شكاوى العاملين بالمنظمة. . توفير وسائل الاتصال المباشرة للعاملون مع الأدارة دون قيود. 8- تطوير قنوات الاتصال مع العاملين بالمنظمة

3 - مؤشرات تخطيطية لتفعيل تطبيق الثفافية الادارية من خلال تفعيل نظام المسائلة والمحاسبية بالمنظمة,حيث يتم تحقيق ذلك من خلال:. . مسائلة المقصرين فى مهام عملهم بثكل صارم داخل المنظمة " ـ اتخاذ اجراءات المسائلة مع جميع العاملين المقصرين بالمنظمة. ـ تتفيذ إجراءات المسائلة بموضوعية على جميع العاملين بالمنظمة. ـ اعلان ماتم التوصل إليه من قرارات بعد اجراءات المسائلة. . توفير نظام واضح للمسائلة داخل المنظمة. . جمع المعلومات اللازمة قبل مسائلة المقصرين من العاملين. . اتباع إجراءات صارمة تحقيقاً للمسائلة العادلة. . الكثف عن أسماء المتورطين بمخالفات قانونية بالمنظمة 
4- مؤشرات تخطيطية لتفعيل تطبيق الثفافية الادارية من خلال تفعيل مشاركة العاملين فى اتخاذ القرارات التى تخدم المنظمة,حيث يتم تحقيق ذلك من خلال:. . اتخاذ القرارات الإدارية على أسس علمية. . تبنى الإدارة إجراءات مكتوبة عند اتخاذ القرارات اللازمة. ت تقبل الإدارة الملاحظات والإقتراحات عند اتخاذ القرارات. . توفير المعلومات اللازمة لعملية صناعة القرارات السليمة. ـ إعلان القرارات الإدارية التى تتخذها المنظمة. . إتباع الإدارة المكاشفة والوضوح عند إتخاذ القرارات. ـ اهتمام الإدارة بأراء العاملين ومقترحاتهم عند إتخاذ القرارات اللازمة. . مشاركة الأطراف المعنية عند اتخاذ القرارات اللازمة. ـ إتخاذ الترارات الإدارية التى تخدم المنظمة فى ضوء مشاركة العاملين بها. ـ الاهتمام بطبيعة آداء العاملين عند اتخاذ القرارات اللازمة. ـ منح العاملين بالمنظمة الصلاحيات اللازمة لاتخاذ القرارات التى تخدم عمل المنظمة. 5- مؤشرات تخطيطية لتفعيل تطبيق الثفافية الادارية من خلال تفعيل اللوائح والإجراءات وأليات العمل التى تخدم المنظمة,حيث يتم تحقيق ذلك من خلال:. . تبصير العاملين بالقوانين والتشريعات المنظمة للعمل. ـ مساندة العاملين بالمنظمة فى تبسيط إجراءات العمل لتحقيقها دون تعطيل. ـ مناقثة الأساليب المناسبة لتنفيذ الإجراءات والقواعد المنظمة للعمل بالمنظمة. ـ مشاركة العاملين بالمنظمة فى تحديد إجراءات العمل تعزيزا للعمل الجماعى. . الإستعانة بأدلة استرشادية لتحديد إجراءات العمل. 
. تطبيق اللوائح والقوانين على الجميع دون استثناء.

. مراجعة الأنظمة واللوائح والقوانين بشكل دورى.

يتم تحديد الإجراءات والضوابط وفقاً لمتطلبات الموقف.

. التعامل بمرونة عند وضع الإجراءات والضوابط.

. تحديد أثر تطبيق الأنظمة والقوانين على بنية العمل..

المرلحع المستخدمة في البحث

1) هلالي ,محمود محمد(2013): الجهات المانحة الدولية والجمعيات الأهلية "رؤية معاصرة لتمويل المشروعات التنموية وبناء القدرات المؤسسية" تقديم : إبراهيم عبد الهادي ، الأسكندرية

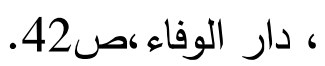

2) سمك,نجوى,صدقى,السيد(2002): دور المنظمات غير الحكومية فى ظل العولمة الخبرتان المصرية واليابانية (مركز الدراسات الأسيوية، كلية الاقتصاد والعلوم السياسية، جامعة

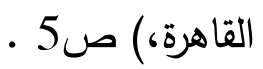

3)حامد,حسين إبراهيم(2009):الإدارة فى المجتمعات المتقدمة,دار المعارف للنشر والتوزيع,القاهرة,ص 53.

4)محمد,عبداللطيف محمد(2017):الشفافية وتطوير الإدارة بمنظمات المجتمع المدنى, بالتطبيق على نقابة المحامين,بجث علىى منشور بمجلة الخدمة الاجتماعية,الجمعية المصرية للأخصائيين الاجتماعيين,العدد 57,الجزء التاسع,يناير .ص459.

5)حوامدة,باسم,جرادات,محمد(0 . † ) ): درجة تطبيق المساءلة الإدارية في المدارسالحكومية في محافظة جرش • مجلة كلية التربية ، جامعة المنصورة ،العدد مه ، الجزء الثاني. المنصورة

6) العمرى,مشرف(2013): درجة ممارسة الشفافية الإدارية فى الجامات السعودية ومعوقاتها وطرق تحسينها كما يتصورها أعضاء هيئة التربس,رسالة دكتوراة غير منشورةكلية التربية,جامعة أم القرى,مكة المكرمة.ص243. 
7)مدكور إبراهيم خالد(2016): معوقات تطبيق الثفافية بالمنظمات الحكومية بالتطبيق على

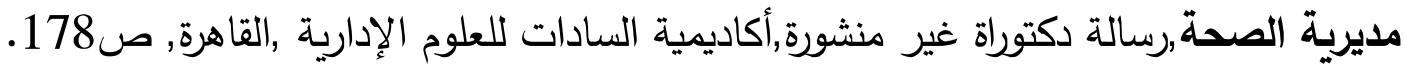

8) الأحمدى,حنان(2017): درجة ممارسة قيادات المدارس المتوسطة للثفافية الإدارية بدينة

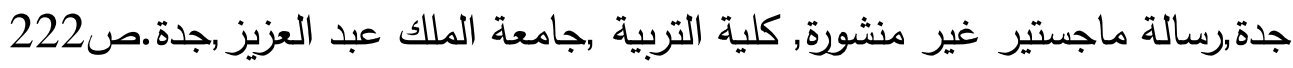
9) Liepertp, Gary(2005):, Building Capacity for decentralized local development in chad, civil society groups and role of nonformal,(USA,the florida state university.

10) Hall Kier Bente,( 2007): Shifting Responsibilities for food safety in Europe:An introduction,Department of communication Journalism and computer science,University Roskilde,Denmark,.

11) Shane,Kite,(2003): Transparency Spies Bonds Innovation(Securities Industry,Septemper,pp10,12

12) Klein,J(2012):The open door policy,Transparency Minimizes Conflicts between School Principals and staff, International Journal of Educational Management,P550.

13) علام ,محمد تركى(2014): ممارسة الثفافية وتدعيم عملية صنع القرار,بحث علمى منشور بمجلة دراسات الخدمة الاجتماعية والعلوم الإنسانية,العدد33,الجزء الأول,كلية الخدمة الاجتماعية,جامعة حلوان. 14) Hazel, Korn,(2012):European Transparency Instruments: Driving the Modernization of European Higher education, Dublin Institute of Technology, Ireland.p8 
15) الجوهري, محمد محمود(1990): حركة المؤشرات الاجتماعية - محاولة تاريخية، بحث

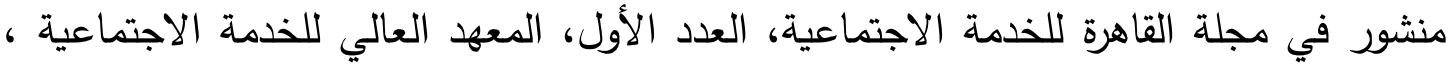

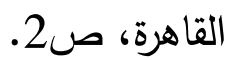

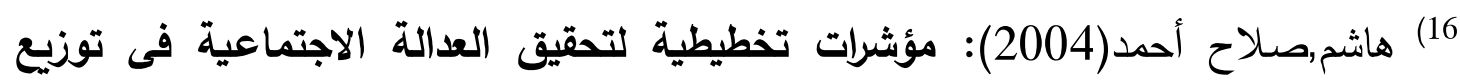

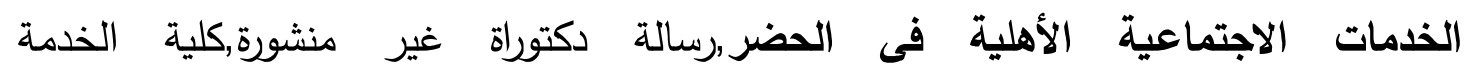

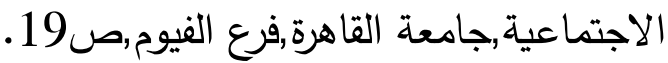
17) السكري,أحمد شفيق(2000): قاموس الخدمة الاجتماعية والخدمات الاجتماعية,دار

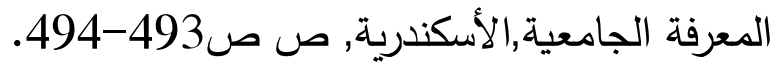
18) السروجي ,طلعت مصطفى(1990): مؤشرات تخطيطية لمواجهة مشكلات الصيادين ببحيرة قارون ، بحث علمي منشور بالمؤتمر العلمي الثالث كلية الخدمة الاجتماعية ركلية

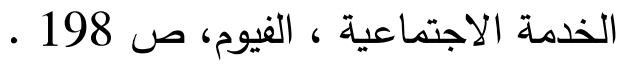
19) Barnes, Barry(1995): The Elements of Social Theory , Biddies LTD, London , P.15 .

20) ناجي ,أحمدعبد الفتاح(2002): تصورات الأبناء كمؤشر فى التخطيط لرعاية آبائهر

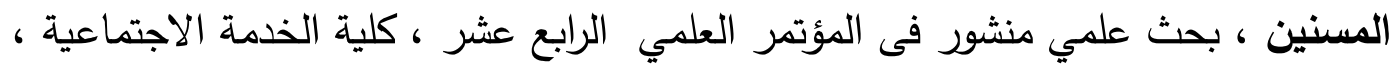
جامعة القاهرة ,فرع الفيوم, ص 28.

21) Enquist, Edvardsson: Quality Improvement in Governmental Services The Role of Change Pressure Exerted by The "Market" , The TQM Magazine, Vol.18,No.1, 2006, pp23,24.

$$
\text { 22) تامر ياسر البكري: تسويق الخدمات الصحية,دار اليازوري,عمان } 2005 \text {, } 167 \text { : } 167 \text { : }
$$

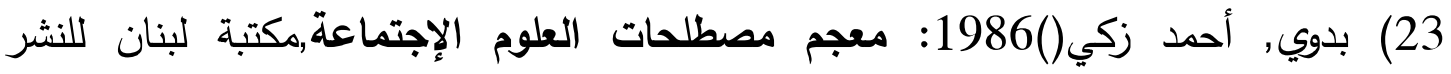

$$
\text { والطباع,بيروت,ص } 399 .
$$

34) الدخيل,عبدالعزيزعبدالله(2012): معجم مصطلحات العلوم الإجتماعة, ط2, , دار المناهج

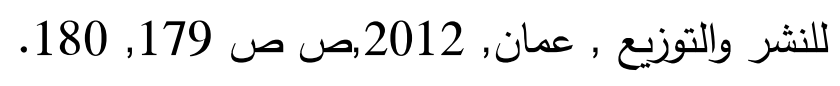

25) أبو النصـر ,مدحت محمد(2009): فـن ممارســة الذدمـة الإجتماعيـة،دار الفجر للنشـر والتوزيع,القاهرة ،ص الصن بمدن 229.

26)Romanov ,Pavel:Quality Evaluation in Social Services:

Challenges for New Public Management in Russia, FACILITIES 
MANAGEMENT SERVICES IN LITHUANIA, Vol. 2, No. 4,2012, p14.

27) Khan

Alfred J(1983).: Social Policy and Social Services,_Second Edition,

Random Hous, New York, p29.

28) Bochel Hugh,Et.el(2005): Social Policy: Issues and Devel

Opments,First Edition,Harlow"England", Pearson Prentice Hall, $p$

29)معجم اللغة العربية(1996):المعجم الوجيز الهيئة العامة لثئون المطابع الأميرية القاهرة,ص10.

30) النازهه,عبير مصلح(2013) والثفافة والكساءلة في مواجهة الفساد، طبعة ثالثة، أمان

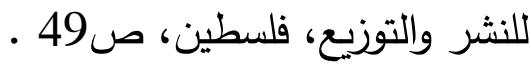

31) مسفر ,فهـ عبد الرحمن(2013): الإدارة بالثفافية لاى مديري التربية والتعليم بمنطقة

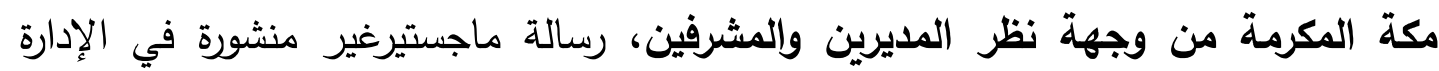
التربوية والتخطيط، جامعة أم القرى،. مكة المكرمة, صنا 1 .

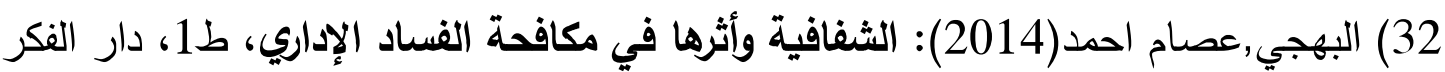

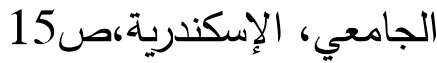
33) مخيمر، عبد العزيز جميل وأخرون، 2000، قياس الأداء المؤسسي للأجهزة الحكومية،

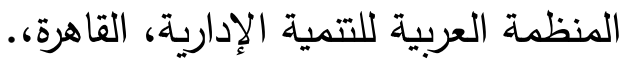

34)(الغالبى,طاهر محن,العامرى,صالح مهاى(2010): المسئولية الاجتماعية وأخلاقيات

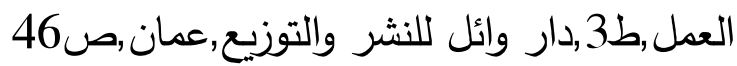
35)نيازى,عبد المجيد بن طاش(2000):مصطلحات ومفاهيمانجليزية فى الخدمة الاجتماعية مكتبة العبيكان,ارياض,ص244.

36)خزام,منى عطية(2010): شبكة الأمان الاجتماعى وتحسين نوعية حياة الفقراء,المكتب الجامعى الحديث,الأسكندرية,صنا2:207 
37)ناجى,أحمدعبدالفتاح(2014):تطوير وتحديث المنظمات التطوعية فى العالم النامى(دداخل وإستراتيجيات),المكتب الجامعى الحديث,الأسكندرية,صص المس (18,17.

38) بدوى, أحمد زكى(1993) : معجم مصطلحات العلوم الاجتماعية (إنجليزي-فرنسيعربي)، بيروت، مكتبة لبنان، ص297.

39) عبد اللطيف, رشاد أحمد(2007) : تنمية المنظمـات الاجتماعية مـخل مهنـي لطريقـة تنظيم المجتمع ، ط1 ، دار الوفاء للطباعة والنشر ، الإسكندرية ، 2007 ، ص 26 ـ

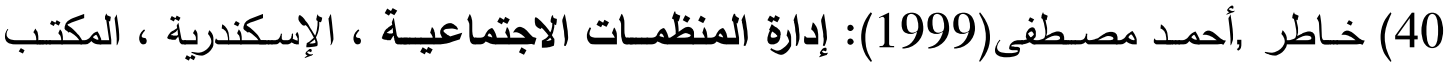

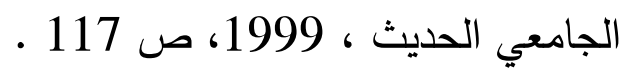
41) قنديل, أماني(1999) : تطور المجتمع المدني في مصر ، القاهرة ، عالم الفكر ، المجلد

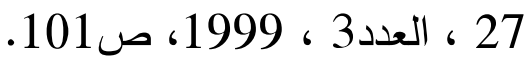

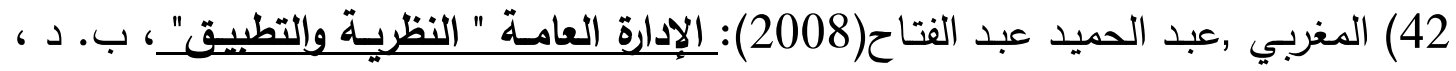

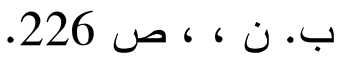

43) محمد, إبراهيم عبدالهادي (2000): الإدارة " مفاهيمها وأنواعها و وعملياتها" ، ، دار المعرفة ، الجامعية ، الأسكندرية ، ص ص ص 251 ، 252 . 251 .

44) شمعان,خليل محمد , حمود خضير كامل(2007): نظريـة (المنظمـة ، ط3، دار المسيرة ،عمان ،

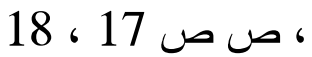

45) Villeneuve,Patric,(2007):Organization Barriers to Transparency,A typology and analysis of Organizational Behavior trending to prevent access to information,(international Review of Adminstrative Sciences, vo73,p147.

46) الجروانى,نادية عبد الجواد(2012): تصور تخطيطى مقترح لتفعيل تطبيق الثفافية فى المؤسسات التعليمية,بحث علمى منشور بمجلة دراسات فى الخدمة الاجتماعية والعلوم الانسانية,العدد (33),ج(1),كلية الخذمة الاجتماعية,جامعةحلوان, القاهرة. 
مجلة كلية الخدمة الاجتماعية للار اسات و البحوث الاجتماعية - جامعة الفيوم 